\title{
Structures controlling volcanic activity within Masaya caldera, Nicaragua
}

\author{
Guillermo Caravantes González ${ }^{\alpha, \beta}$, Hazel Rymer ${ }^{\star \alpha}$, Jeffrey Zurek $\gamma$, \\ Susanna K. Ebmeier ${ }^{\delta}$, Stephen Blake ${ }^{\alpha}$, Glyn Williams-Jones $\gamma$ \\ ${ }^{\alpha}$ School of Environment, Earth and Ecosystem Sciences, The Open University, Milton Keynes, MK7 6AA, UK. \\ $\beta$ GeoArc Foundation, Monte Esquinza 28, 28010 Madrid, Spain.

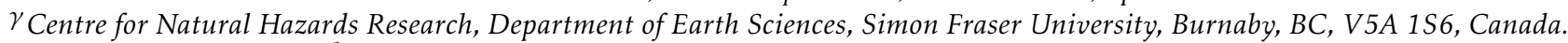 \\ ${ }^{\delta}$ School of Earth and Environment, University of Leeds, Leeds, LS2 9JT, UK.
}

\begin{abstract}
Geophysical and geological observations collected in 2007-2012 shed light on the mechanisms controlling the style and location of eruptions within the Las Sierras-Masaya Caldera complex, Nicaragua. These results confirm a hypothesised $\sim 3.5 \mathrm{~km}$ diameter structure with features compatible with the presence of a ring fracture $\left(50-65^{\circ}\right.$, with inward-dipping bounding walls). A central block is bound by this fracture and defines an incipient nested caldera related to the emptying of the magma chamber following the last Plinian eruption (1.8 ka). The prolongation of the Cofradías fault from the Managua graben represents the most significant structure on the floor of Masaya caldera. Current activity, including a convecting lava lake, largely depends on the interplay between the extensional stress regime associated with the Managua graben and deformation along the inner caldera bounding fault. This high spatial resolution survey uses a novel combination of geophysical methodologies to identify previously overlooked foci for future volcanic activity at Masaya.
\end{abstract}

\section{RESUMEN}

Las observaciones geofísicas y geológicas recopiladas del 2007 al 2012 esclarecen los mecanismos que controlan el estilo y la ubicación de las erupciones dentro del complejo Las Sierras-Masaya, Nicaragua. Estos resultados confirman una estructura hipotética de $\sim 3,5 \mathrm{~km}$ de diámetro, cuyas características son compatibles con la presencia de una fractura anular $\left(50-65^{\circ}\right.$, con muros delimitadores inclinados hacia el interior). Un bloque central delimitado por esta fractura define una caldera interior incipiente relacionada con el vaciado de la cámara magmática después de la última erupción pliniana $(1.8 \mathrm{ka})$. La prolongación de la falla de Las Cofradías del graben de Managua representa la estructura más significativa en el suelo de la caldera de Masaya. La actividad actual, incluido un lago de lava altamente convectivo, depende en gran medida de la interacción entre el régimen de estrés extensional asociado con el graben de Managua y la deformación a lo largo de la falla que delimita la caldera interior. Este estudio de alta resolución espacial utiliza una combinación novedosa de metodologías geofísicas para identificar lugares previamente ignorados para la futura actividad volcánica en Masaya.

Keywords: Masaya volcano; Structure; Ring fracture; Caldera; InSAR; VLF; Magnetics

\section{InTRODUCTION}

Masaya volcano is one of the best-known volcanic edifices within the Nicaraguan volcanic chain due to its accessibility and relatively non-hazardous persistent activity. However, this basaltic caldera has also been the source of three basaltic tephras over the last 6000 years, produced by highly explosive eruptions that have spread pyroclastic deposits over a large area of Western Nicaragua [Williams 1983a; Pérez and Freundt 2006; Kutterolf et al. 2008; Pérez et al. 2009]. Although the exact source location of some of the deposits is uncertain, description of the deposits has enabled vol-

${ }^{*}$ Corresponding author: hazel.rymer@open.ac.uk ume estimates to be made. The most recent eruption, the Masaya Tuff is a major and extremely violent phreatomagmatic eruption ending in a Plinian phase and probably transitioning into voluminous lava effusions which created the present day inner configuration of the caldera. The Fontana deposit was previously thought to originate within Masaya caldera, but is now thought to have a source vent just to the NW and outside the caldera [Wehrmann et al. 2006]. The relative sizes and dates of the eruptions are summarized in Table 1 .

The importance of Masaya caldera derives from the fact that it is located less than $15 \mathrm{~km}$ from Managua, the capital and largest city in Nicaragua $(>1,142,000$ inhabitants, 2005 census), and one of the most populated 
Table 1 - Basaltic Plinian eruptions from Masaya caldera.

\begin{tabular}{rcc}
\hline Name and type of deposit & Total volume $\left(\mathrm{km}^{3}\right)$ & Age $(\mathrm{ka})$ \\
\hline Fontana Lapilli (uncertain origin) & $1.4-1.8$ & $\sim 30$ \\
San Antonio Tephra & 14 & 6 \\
Masaya Triple Layer & 3.6 & 2.1 \\
Masaya Tuff + Ticuantepe Lapilli & 10 & 1.8 \\
\hline
\end{tabular}

Data from Pérez et al. [2009], Costantini et al. [2009], Kutterolf et al. [2008], Pérez Fernández [2007], and Wehrmann et al. [2006].

urban areas in Central America (Figure 1). Masaya caldera is $11 \mathrm{~km}$ long and $6 \mathrm{~km}$ wide and elongated WNW-ESE possibly through interaction with the Managua graben [Girard and van Wyk de Vries 2005]. Faulting is younger and possibly more active in the vicinity of the caldera; either because the basement fault bifurcates as it cuts freshly deposited material above or because of volcanic loading [Girard and van Wyk de Vries 2005]. The irregular and elongated shape of the caldera reflects its complex evolution and tectonic setting. Caldera classification is challenging in this environment, but we suggest that it is most similar to a trap-door type [Cole et al. 2005]. Growing within the caldera is a volcanic cone rising $300 \mathrm{~m}$ above its surroundings in the middle of its north-western portion. This cone, containing four pit craters (including one, Santiago, which currently hosts an active lava lake), is the source for most of the historic activity that has taken place within the caldera. There are also a number of other important volcanic centres on the caldera floor, some of which have been named. Most of these are distributed along suspected or inferred structures, such as a semi-circular feature in the north-western half of the caldera, faults geometrically related to the Cofradías fault of the Managua graben and others. The boundaries of Masaya caldera are delineated by near vertical cliffs up to $200 \mathrm{~m}$ tall. Approximately $2 \mathrm{~km}$ out of the $40 \mathrm{~km}$ perimeter of the caldera boundary is indistinct as it is covered by lavas emitted from the central volcanic edifice. A shallow lake fills the easternmost side of the caldera, bordering the city of Masaya.

Past studies of Masaya caldera provide important insights into many aspects of volcanic activity in the area. Studies such as those by Burton et al. [2000], Lewicki et al. [2005], Mather et al. [2006], Witt et al. [2008], Nadeau and Williams-Jones [2009], Padilla et al. [2014], Aiuppa et al. [2018], and Stix et al. [2018] have characterised in detail the chemical signature and properties of Masaya volcano's gas plume and provided information on degassing occurring elsewhere on the caldera floor. Duffell et al. [2003], Moune et al. [2007], Stix [2007], Branan et al. [2008], and Stephens et al. [2017] have investigated the vent system and dynamics. Several gravity studies [e.g. Connor and Williams 1989; Métaxian 1994; Bonvalot et al. 1995; Rymer et al. 1998;
Locke et al. 2003; Williams-Jones et al. 2003], have revealed information on Masaya's sub-surface density structure. Several detailed geological studies deal with Masaya's structural evolution and eruptive history, e.g. McBirney [1956], Williams [1983a], Rymer et al. [1998], Roche et al. [2001], Girard and van Wyk de Vries [2005], Harris [2009], and Zurek et al. [2019]. The role and effects of explosive activity from Masaya have also been investigated, e.g. Williams [1983a], Williams [1983b], Pérez and Freundt [2006], Pérez Fernández [2007], and Pérez et al. [2009]. The groundwater and hydrothermal systems at Masaya have been studied by Lewicki et al. [2003], MacNeil et al. [2007], Pearson et al. [2008], Pearson [2010], and Mauri et al. [2012].

Despite the numerous studies, insufficient geological and geophysical data has been collected from the caldera floor to unequivocally establish the characteristics and geometry of its structural framework and assess its influence on Masaya's magma plumbing and hydrothermal systems. Although the existence of a ring fault in the area has been suggested based largely on the distribution of vents on the caldera floor [e.g. McBirney 1956; Viramonte 1972; Crenshaw et al. 1982; Mauri et al. 2012], some areas remain relatively unknown due to factors such as the small size of the volcanic centres or limited accessibility. Furthermore, evidence for relative motion and the geometry at depth, the specific role faults play regarding volcanic activity, and the rate and style of deformation, is lacking.

In this study we combine magnetic, Very Low Frequency Electromagnetic (VLF) and Interferometric Synthetic Aperture Radar (InSAR) data for Masaya caldera to investigate the surface and sub-surface structures. The objective of this research is to generate a comprehensive model that explains the long-term behaviour of Masaya caldera and its structural framework. This allows us to identify the mechanisms that control eruptive activity at present, and to correlate past eruptive events with present day features, thus providing a better understanding of the evolution of the caldera. It is also a key element to improve effective forecasting of Masaya volcano's future eruptive behaviour. 

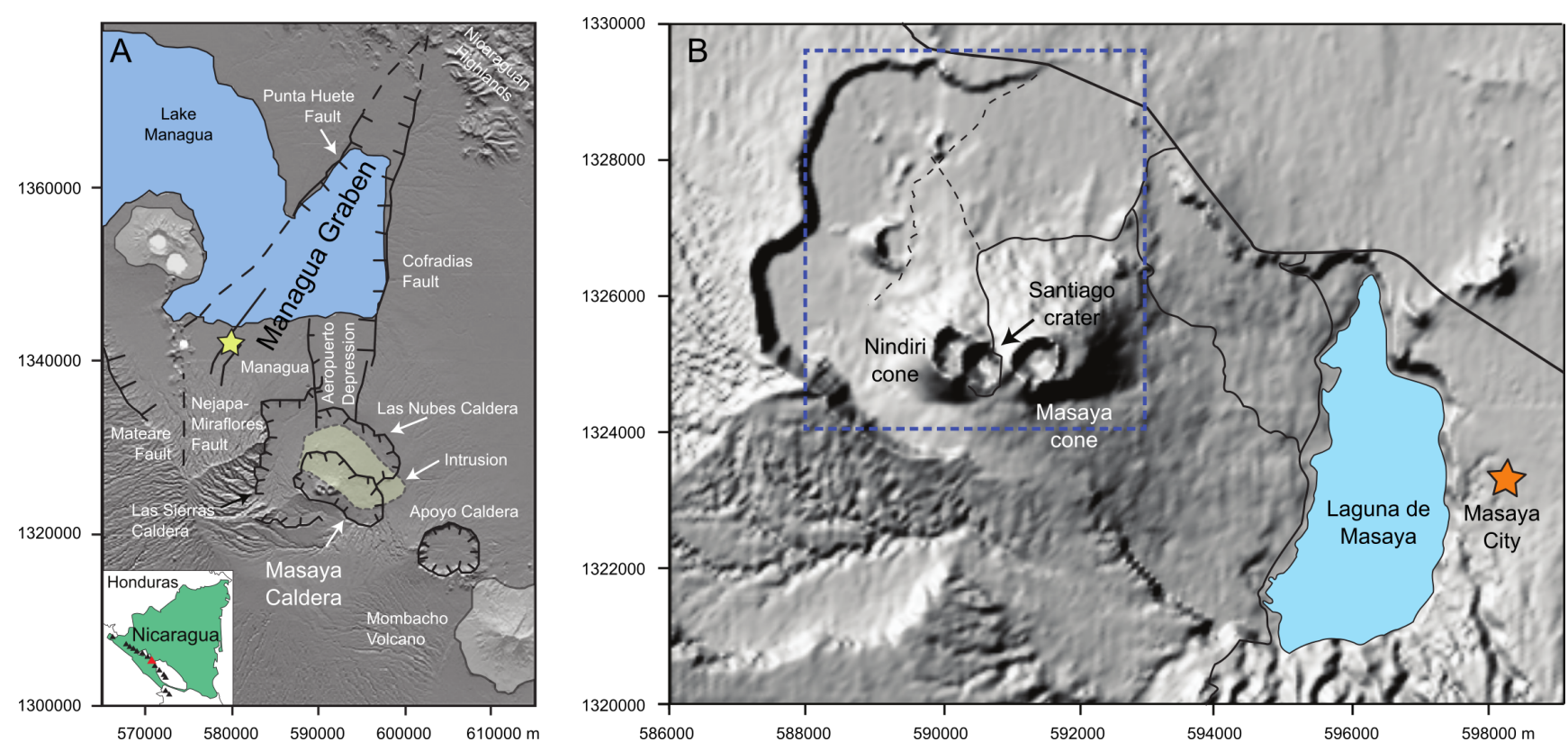

Figure 1: [A] Location of large tectonic features near Masaya Caldera (modified from Girard and van Wyk de Vries [2005]). Inset map of Nicaragua with volcanoes of the Central American Volcanic Arc shown by black triangles; Masaya is shown by a red triangle. Managua City (yellow star) lies within the Managua Graben depression, with the adjacent Masaya Caldera located in the prolongation of the Cofradías Fault, the eastern bounding fault of the Managua Graben. [B] Shaded relief map of Masaya caldera with the main Nindiri and Masaya cones and active Santiago crater shown. Masaya City is shown by an orange star. Blue dashed box indicates area shown in Figure 2. UTM zone 16.

\section{Regional SETting AND VOlCANiC ACTIVITY}

Masaya caldera (Figure 1) is the most recent of a series of nested calderas within the Las Sierras-Masaya Volcanic Complex, a basaltic shield volcano which is the largest Quaternary volcano in Nicaragua [van Wyk de Vries 1993; Sebesta 1997; Girard and van Wyk de Vries 2005]. Masaya is associated with a dense intrusion to the NW (as suggested by gravity studies, e.g. Métaxian [1994]) and a similarly sized relict caldera (Las Sierras-Las Nubes caldera), probably generated at 60,000 ka by the eruption of a large basaltic ignimbrite [Bice 1980; Sebesta 1997; van Wyk de Vries 1993; Wehrmann et al. 2006; Kutterolf et al. 2008]. The Masaya caldera within the Las Sierras-Masaya Volcanic Complex has been linked tectonically with the Managua graben, an active pull-apart basin [Sebesta 1997; Girard and van Wyk de Vries 2005]. This extensional volcanic setting has had major effects on the structural framework of the volcano. One effect of the extensional stress regime in the area is probably the continuous supply of magma that feeds volcanic and degassing processes taking place in the summit area at present [e.g. Stoiber et al. 1986; Burton et al. 2000; Williams-Jones et al. 2003; Witt et al. 2008; Nadeau and Williams-Jones 2009; Stix et al. 2018; Zurek et al. 2019; Pering et al. 2019]. Several fracture systems coherent with the local stress regime are visible on the caldera floor and seem to be correlated in certain cases with different phases of activity at the volcano. For example, the 1772 effusive fissure eruption originated from a fracture geometrically linked with the Cofradías fault, the easternmost bounding fault of the Managua graben [Crenshaw et al. 1982; Williams 1983a; Mauri et al. 2012].

Masaya volcano is one of only a few systems showing basaltic Plinian activity, with three Plinian eruptions during the last $6 \mathrm{ky}$, the last one having taken place at around 2000 years BP [Williams 1983a; van Wyk de Vries 1993; Pérez and Freundt 2006; Pérez et al. 2009]. However, Masaya's activity is dominantly characterised by periods of long-lasting persistent degassing, effusive eruptions and minor vent-clearing explosions.

Over the last 160 years, at least 5 major degassing periods have been recorded [Stoiber et al. 1986; Rymer et al. 1998; Williams-Jones et al. 2003]. In 1993, the most recent degassing period at Masaya started [Rymer et al. 1998] after four years with significantly lower levels of gas flux. Since then, activity has consisted of persistent degassing from a small vent (within Santiago crater; Figure 1) that fluctuates in intensity over time. For the period 1980-2017, Zurek et al. [2019] estimated that an average of $\sim 1,050$ metric tonnes of $\mathrm{SO}_{2}$ were emitted daily $\left(\mathrm{td}^{-1}\right)$ from the active vent. Diffuse 
degassing from the Masaya volcanic edifice was also estimated to contribute $295 \mathrm{td}^{-1} \mathrm{CO}_{2}$ in 2008 [Padilla et al. 2014]. This persistent degassing is supported by the efficient convection of fresh gas-rich magma [WilliamsJones et al. 2003; Stix 2007] to the shallow sub-surface, evidenced by continuous tremor [Métaxian et al. 1997; Pezzo et al. 2001] and oscillation in the magma level visible in the intracrater vents in Santiago crater.

\section{Methods ANd Results}

\subsection{Structural survey}

\subsubsection{Ground-based structural survey}

A thorough geological and topographical survey was conducted within the limits of the caldera in JanuaryMarch 2010 and 2011, with the scope of delineating features that might have played an important role in controlling Masaya volcano's activity. Large scale/active structures are also the most likely to produce recognisable disruptions on the surface through lateral displacement and subsidence. The most common materials on the floor of Masaya caldera are successions of ash and lavas, and locally, sparselyvegetated recent lava flows. Several features have been identified (Figure 2; Appendix 1), many of which are relevant for reconstructing the geological history of the caldera and understanding its current structural framework. Cooling fractures, lava tubes, and prominent edges of lava flows are not described in this study as they provide little information on the volcano's structural framework. Rather, the features that can be directly linked to the volcano's structural framework, especially those forming a circular pattern in the NW portion of the caldera (Figure 2; Appendix 1), are described below.

\subsubsection{Openings and fractures}

O1 openings are not eruptive vents. Confined to the heavily fractured terrain in the northern part of the caldera (Figure 2), they tend to follow a braided pattern, have typical widths between 0.1 and $2 \mathrm{~m}$, depths between 2 and $10 \mathrm{~m}$, and variable lengths that range from $2-5 \mathrm{~m}$ for the shortest to $100 \mathrm{~s} \mathrm{~m}$ for the longest (Figure 3A). After recognition in the field, their location, lateral extent and orientation were compiled using satellite imagery (see Ground-based structural survey). $\mathrm{O} 2, \mathrm{O} 3$ and $\mathrm{O} 4$ openings all have depths that range from 2 to $10 \mathrm{~m}$, and a V-shaped morphology with a bottom deeper than their surroundings.

\subsubsection{Fumaroles}

In addition to the persistently degassing Santiago vent in the summit area (Figure 3B), six other sites (Figure 2, from west to east, F2-F7) with intermittent (F2F3-F5-F6) or persistent (F1-F4-F7) fumarolic activity
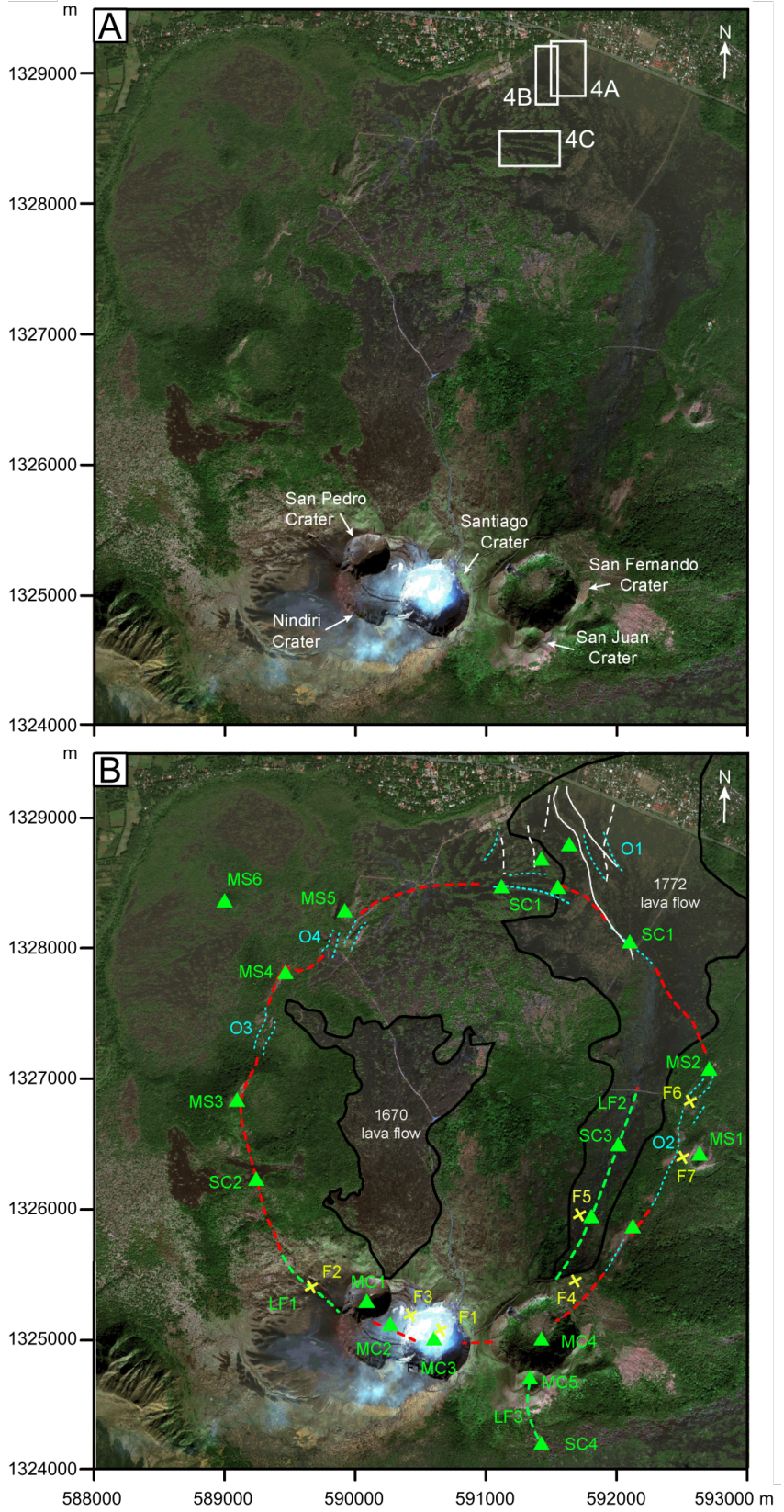

Figure 2: Location of relevant structural features within Masaya Caldera. [A] Image of the northern part of Masaya caldera. White boxes and 4A, B, C denote areas presented in Figure 4. [B] Annotated image. Red dashed line approximates the surface trace of a circular structure based on the alignment of structural evidence. Green triangles represent eruptive centres, including the main pit craters (MC), medium sized cones (MS) and spatter cones/ramparts (SC). Yellow X symbols represent fumaroles and degassing spots $(\mathrm{F})$. Green dashed lines represent large fissures (LF) source of past eruptions. Cyan lines represent openings, fractures and cracks $(\mathrm{O})$. White continuous lines represent inflation fractures, white dashed lines indicate fractures parallel to the Cofradías fault. See Appendix 1 for details. The 1670 and 1772 lava flows are outlined in black. Base image from ESRI World Imagery, UTM zone 16. 
have been identified on the caldera floor. These include: F2 - Large Fissure Site, a fumarole area within a large fissure on the slope to the west of San Pedro pit crater, with sulphur deposits and intermittent fumarolic activity over the period 2009/2012; F3 - Bee Site, a low temperature fumarole active since 2011 on the northern fracture that limits Nindiri lava lake in the summit area, where the presence of humidity attracted a bee colony (Figure 3G; Erenler et al. [2016]); F4 - Hilltop Site, a fumarole field on the Northern slope of San Fernando cone [Lehto 2007]; F5 - Fumarole Field Site, a small fumarole field in the middle part of the fissure on San Fernando's North slope and source for the 1772 eruption [Lehto 2007]; F6 - Road Site, a 10 mlong, $0.2 \mathrm{~m}$-wide fumarole area along the main road that connects the Park entrance with the summit area, with temperatures of up to $60^{\circ} \mathrm{C}$ and barely visible gassteam emissions; and F7 - Comalito Site (Figure 3C), a hydrothermal area on Comalito cone [e.g. Lewicki et al. 2003; Lewicki et al. 2005; Pearson et al. 2008; Witt et al. 2008] also classified as a diffuse degassing structure (DDS) by Chiodini [2005] and Mauri et al. [2012]. F3 and F6 were previously undescribed in the literature.

\subsubsection{Large fissures}

At least three relatively deep (3-30 m depending on local topography and section) and wide $(10-60 \mathrm{~m})$ eruptive fissures, coming down from San Pedro (LF1, Figure 3F), San Fernando (LF2) and San Juan (LF3) craters, with NW-SE, NNE-SSW and N-S orientations, respectively, are the most important linear features (relatively long, 1.5-2 km) within Masaya caldera; they also represent three of the most prominent features within its boundaries (Figure 2). The first two were the source of historic fissure eruptions, notably the 1772 and 1670 lava flows [Williams 1983a]. The valley running down from San Juan crater (LF3) presents large spatter cones and ramparts along its path and further shows that these fractures have acted as an open path and connection at depth with the magmatic plumbing system during historical times.

\subsubsection{Other eruptive centres}

We also documented other features that provide evidence for eruptive activity within the caldera following the last Plinian eruption at $1.8 \mathrm{ka}$ [Pérez et al. 2009]. These features reflect the operative connection of an underlying magma plumbing system with the surface. They range in size from 300-m-high volcanic edifices to small-scale (less than $1 \mathrm{~m}$ ) lava constructs. These eruptive features encompass the semi-circular alignment of cones and pit craters that form the most significant volcanic centre within the caldera. From West to East (Figure 2), we find San Pedro crater (MC1), Nindiri crater (MC2), Santiago crater (Figure 2: MC3, Figure 3B) and San Fernando crater (MC4). There is also a smaller crater to the South of San Fernando, called San Juan
(MC5). For a more detailed description of these craters, see Rymer et al. [1998] and Harris [2009]. There are also several medium sized (Figure 2, MS) cinder cones which mark the location of recent eruptions that have taken place away from the present centre of activity. These include the relatively large $(>50 \mathrm{~m}$ above the caldera floor) Comalito (MS1), Visitor Centre (MS2) and Cerro Montoso (Figure 2: MS3, Figure 3D) cones and the smaller Cerro Arenoso (MS4), Sastepe (MS5) and Bejucal (MS6) cones. Spatter cones and spatter ramparts, with heights between 1 and $10 \mathrm{~m}$, and very short lateral extension, have also been found. In some cases (Figure 2, SC1), they are associated with fractures that cut through the historically recorded lava flows (1670 and 1772). At least 4 areas outside the volcanic centres already mentioned host these types of features: spatter cones in the North Fracture Field (SC1) are the most important, since at least five of these features can be found in this area, generally clearly associated with openings and cracks. One single spatter rampart was also found South of Cerro Montoso (SC2), and other cones and ramparts associated with large fissures (LF2 and LF3) and fractures (O3) have been found North of San Fernando (SC3), South of San Juan (SC4) Craters, and between Cerro Montoso (MS3) and Cerro Arenoso (MS4); all are indicative of fissure eruptions in the area.

\subsubsection{Remote sensing structural survey}

The inherent characteristics of 'A' $\bar{a}$ lava flows can hinder research efforts directed towards understanding the stress fields that affect them. The weak and easily collapsible nature of the terrain (due to the rapid cooling of the lavas, hydrothermal alteration and other factors) and the profusion of lava tubes underlying the superficial lava crust in certain areas of Masaya, make it difficult to intensively survey some locations on the caldera floor. The uniformity in colour and texture of lava deposits can also make it difficult for observers on the ground to distinguish different generations of fractures. Thus, the ground-based survey data (also used as control points) was integrated with Google Earth ${ }^{\mathrm{TM}}$ imagery to facilitate identification of patterns, in particular in the fracture field in the Northwest part of the caldera. Since the surface is covered by the recent 1772 lava flow, any faults, fractures and collapses not associated with lava flow dynamics will be an indication of recent processes. Several sets of features with the potential of revealing information on the stress fields in this area have been identified and classified into three categories that reflect their geometrical and geomorphological characteristics (Figure 4). A first set of fractures (Figure 4A) can be found within, but subparallel to the edges of, some lobes of the 1772 lava flow (emitted from San Fernando's fissure, Figure 2, LF2). They tend to possess a high degree of lateral continuity, and normally appear in the field as sets of 5$10 \mathrm{~m}$ deep braided fractures occupying 10-30 m wide paths that separate areas of relatively thick and com- 

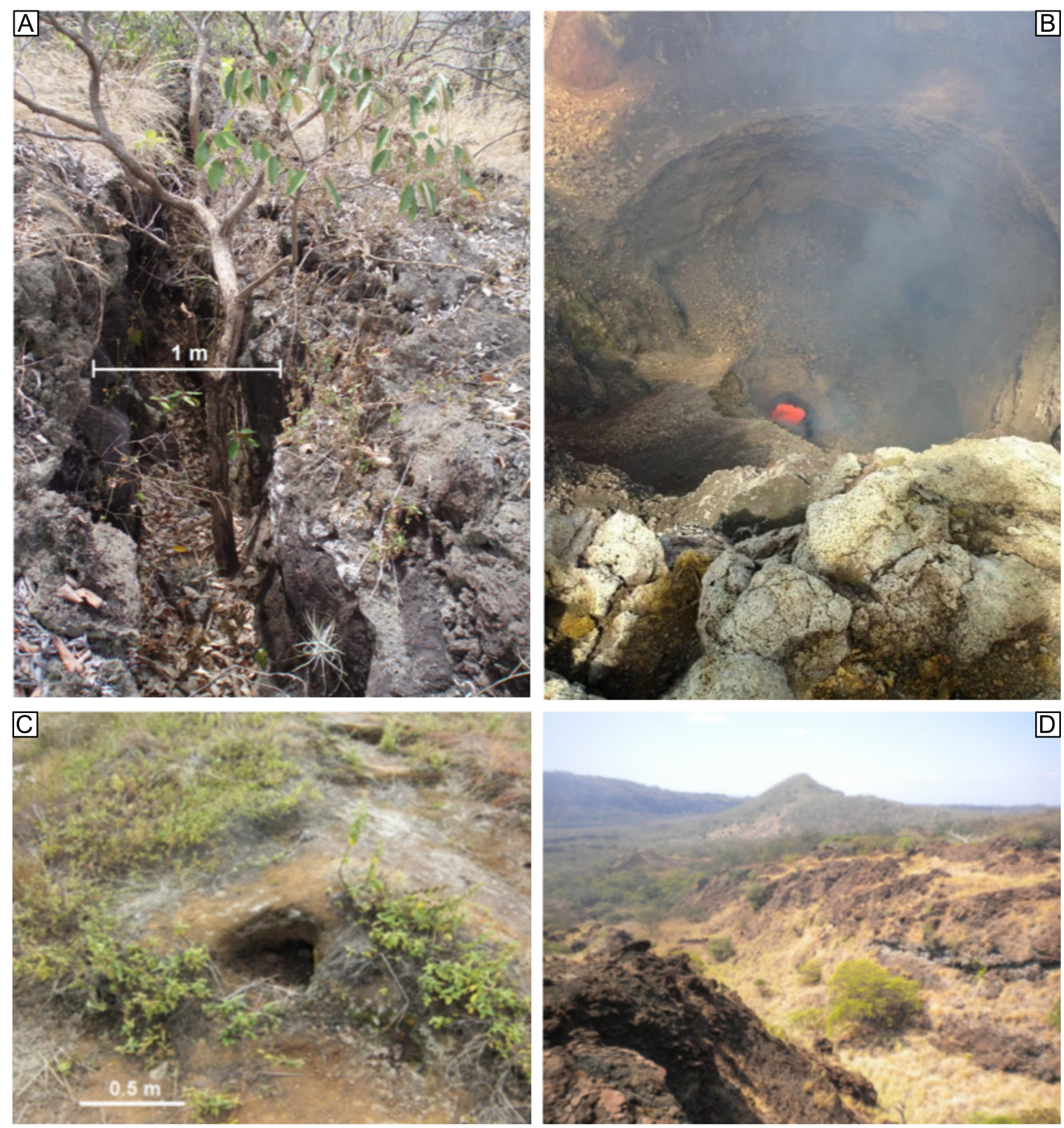

Figure 3: Examples of [A] recent opening or crack (O1); [B] active vent in Santiago crater (MC3); [C] fumarole in Comalito (F7); [D] cinder cone in Cerro Montoso (MS3). [Continued on next page.]

pact lava packages. The cumulative width of these openings can reach (depending on the section) up to 10 $\mathrm{m}$. The formation of these fractures is likely related to lava inflation processes [e.g. Anderson et al. 1999; Chitwood 1994; Hon et al. 1994; Rossi and Gudmundsson 1996; Walker 1991] during emplacement of the 1772 lava flow. A second set of fractures (Figure 4B), next to several families of the first set, also appear within the area covered by the 1772 lava flow. These fractures run up to $200 \mathrm{~m}$ in length and normally are 1-6 m deep. Small spatter cones (1-3 m above surrounding terrain) can be found associated with this type of fracture. Their orientation (NNE-SSW) and disposition on the caldera floor suggest they might share a structural link with San Fernando's large fissure (Figure 2, LF2), and at a larger scale, with the easternmost boundary of Managua graben (Cofradías fault). The third set of fractures (Figure 4C), also locally associated with small $(0.5-8 \mathrm{~m})$ spatter cones and ramparts, occupies a position consistent with the expected location of the North- 

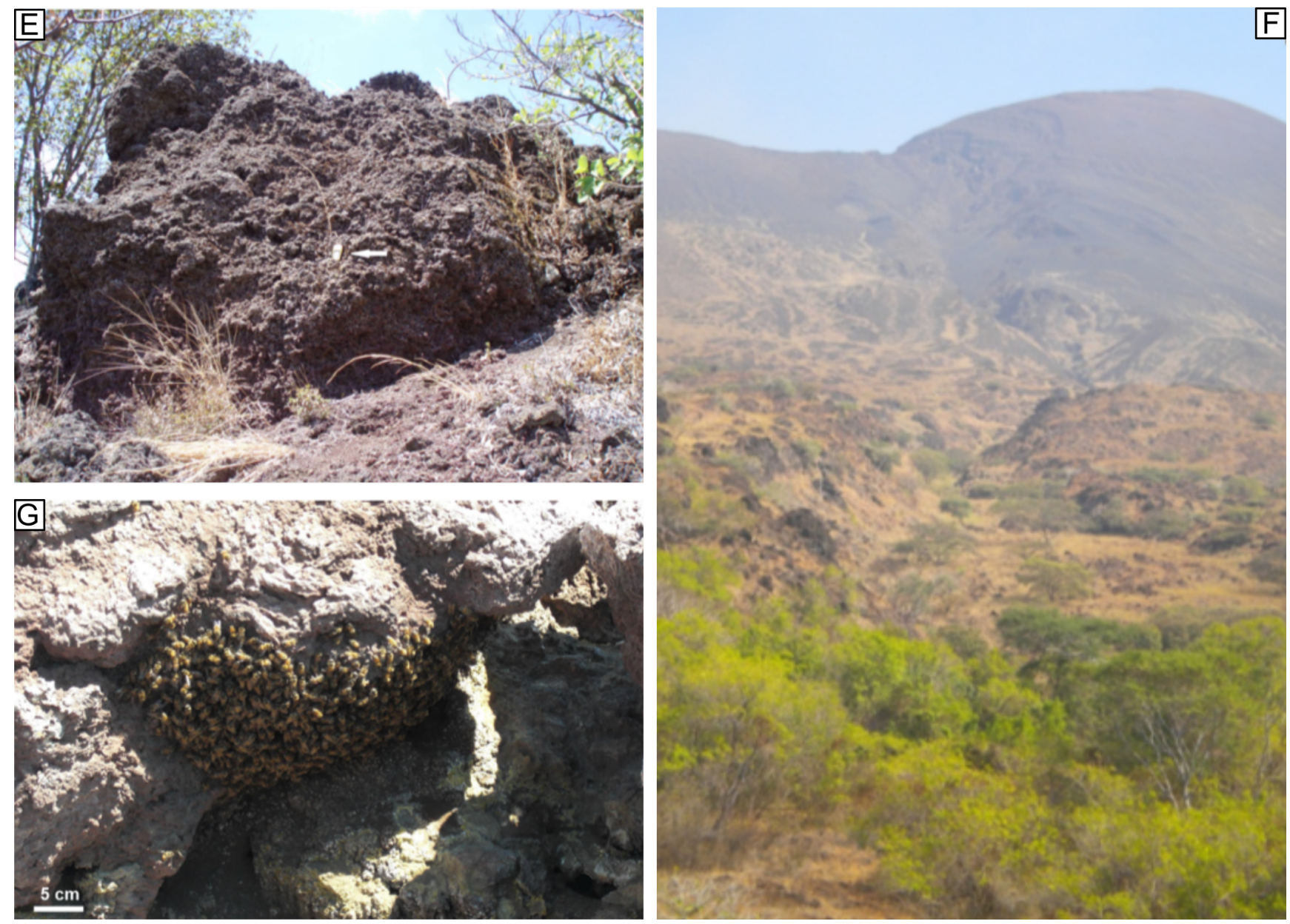

Figure 3: [cont.]: [E] spatter rampart (SC1); [F] fissure in San Pedro (LF1); [G] fumarole in Nindiri covered by bees attracted by the moisture (F3).

ern section of a circular structure that can also be seen in the West, East and South sections as a W-E semicircular alignment of cones and pit craters. Despite the relatively shallow depth of the collapse features (2$5 \mathrm{~m})$, the degree of continuity of this last set of fractures $(500-800 \mathrm{~m})$ and the disposition in collapse areas parallel among themselves, cannot be explained by random mechanisms. The lesser depth of the fractures compared to the other sets may be the result of slow and gradual collapse of a central block within the caldera limited by a boundary fault, which has remained active following the 1772 eruption.

\subsection{Magnetic anomalies}

The main source for variations in the magnetic field in volcanic terrains is the thermo-remnant magnetization of rocks after they have cooled below the Curie temperature $\left(585^{\circ} \mathrm{C}\right)$. The high concentration of ferromagnetic minerals in basalts makes mafic volcanoes a good setting for magnetic studies, since the presence of basaltic dikes (evidence of deep fracturing) can gen- erate important magnetic anomalies, and therefore become good indicators of structural features [e.g. Stamatakos et al. 1997; Connor et al. 1997; La Femina et al. 2002; Lopez-Loera et al. 2010; Pearson et al. 2012]. A disadvantage of this method is the numerous short wavelength features that can be found in the data due to the inhomogeneous superficial distribution of volcanic rocks/sediments. Therefore, in order to effectively interpret magnetic anomalies, these anomalies must be well above the signal-to-noise ratio. In this particular geographic location, buried bodies with higher remnant magnetization values tend to generate dipolar anomalies with a positive response south and a negative response north of the object. A previous study by Pearson et al. [2012] in a small area within Masaya caldera (around San Fernando fissure, LF2, Figure 2) showed a NE-SW trending magnetic anomaly of $2300 \mathrm{nT}$ corresponding with the outline of a previously known fault.

A magnetic study covering the caldera floor was completed using a Proton Precession Magnetometer. The height of the magnetometer sensor was $3 \mathrm{~m}$ above the surface. Total magnetic data from 2756 stations with a $25 \mathrm{~m}$ average spacing (69 line-kilometres) were col- 

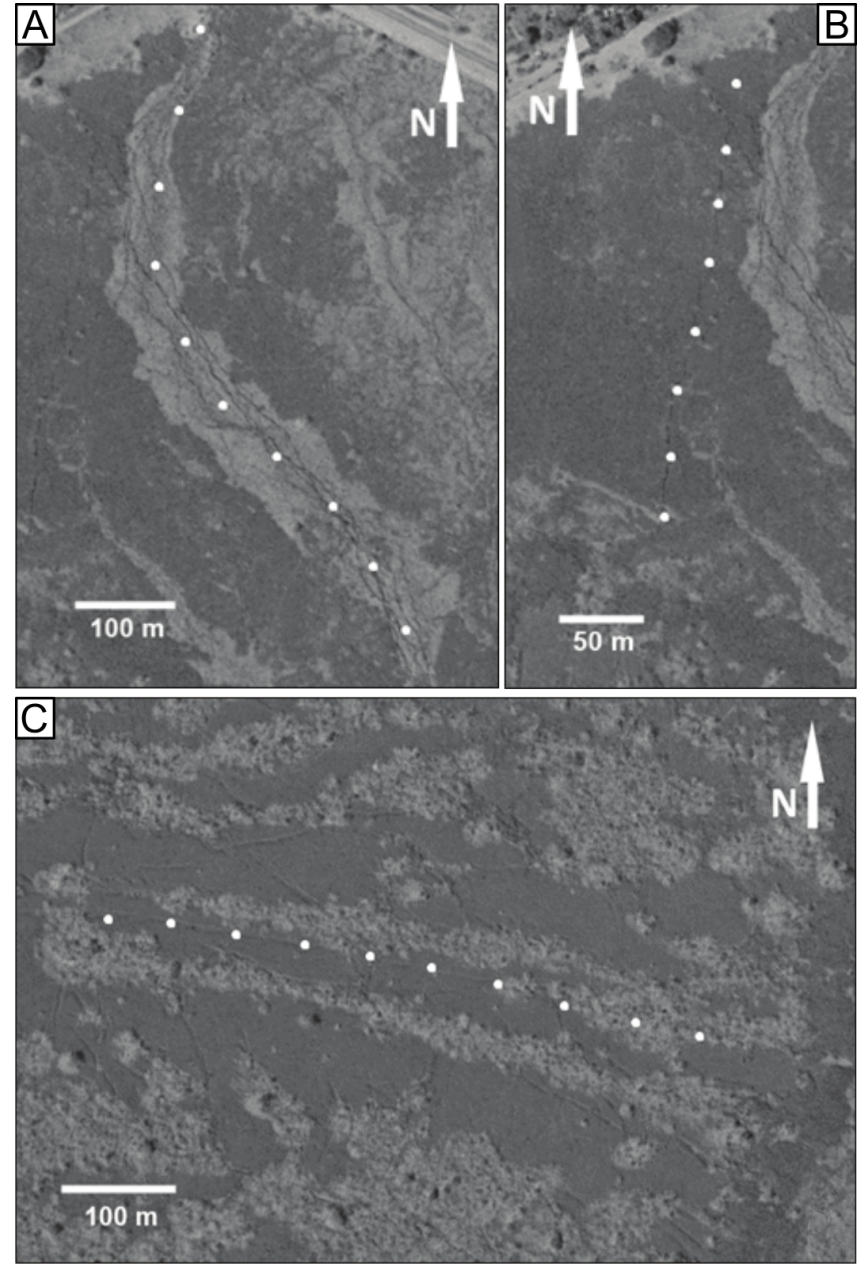

Figure 4: Aerial images of the Northwest fracture field (SC1 and $\mathrm{O} 1$ in Figure 2). White dots delineate [A] braided inflation fractures; [B] Cofradías fractures, and [C] double circular fault fractures (trees align along these subsided areas due to moisture accumulation).

lected in March of 2009 and 2010. A continuously recording magnetometer with a $0.2 \mathrm{~Hz}$ sampling frequency was deployed as a base station for two days for each field campaign in order to help characterize the magnetic diurnal variation in the study area (Figure 5). The short-term diurnal variations (typically less than $50 \mathrm{nT}$ per day but up to $250 \mathrm{nT}$ on 13 March 2010 due to base station instrument malfunction) have very small amplitudes compared with the scale of the variations encountered along the survey lines (thousands of $\mathrm{nT}$ ). Measurements were also repeated every 4-5 stations in order to detect the possible effects of magnetic storms. The measured anomalies were so much larger than errors due to these causes that corrections were not necessary. The magnetic data collected on the caldera floor (with a large dynamic range of up to $15,000 \mathrm{nT}$ due to the strong remnant magnetisations of the basaltic material) shows different characteristics for different parts of the caldera (Figure 6). Observed magnetic data along the shoreline of Masaya Lake shows a high degree of variability, coinciding with an area where the groundwater flows towards the lake [Mauri et al. 2010; Mauri et al. 2012] and has been suggested to be close to the surface [MacNeil 2006; MacNeil et al. 2007]. Strongly variable data (shown by two bodies in bright red, Figure 6) in the intersection between the Northernmost tip of the lake and the caldera boundary (with values oscillating between 32,000 and 38,000 nT) are related to Nindiri's sewage system that transports the city's waste waters into the lake. The profile along the SW boundary of the caldera shows values which, albeit high, are the least variable on the caldera floor, indicating a relatively homogenous lithology/structural framework. The central and NW region of the caldera shows a high degree of variability. To provide more detail on this area, where the existence of a ring fault has been suggested [e.g. Crenshaw et al. 1982], 6 magnetic anomaly profiles are shown in Figure $6 \mathrm{~A}-\mathrm{F}$. They show a good correlation between the independently suggested location of the ring fracture (red arrows) and magnetic dipoles.

\subsection{VLF}

Highly electrically conductive bodies can be detected with the VLF (Very Low Frequency) electromagnetic method. This method has proved successful in studying the hydrothermal system of volcanic edifices [Zlotnicki et al. 2006], detecting conductive structures such as mineralised or water-bearing dikes, fractures and cavities [Zlotnicki et al. 2006; Al-Oufi et al. 2008], and studying sub-surface molten lava within lava tubes, fissures and lava lakes [Zablocki 1978]. The high resistivity of basaltic volcanic successions allows relatively high $(\sim 100 \mathrm{~m})$ penetration depths as a result of very low background noise levels.

Thus, to complement a detailed survey carried out in the summit area [Caravantes Gonzalez 2013], three VLF profiles were completed on the caldera floor (Figure 7). With an average of $20 \mathrm{~m}$ spacing between observation points, they provide information on Masaya's structural framework. The main objective of this VLF survey was to locate and identify dikes and fractures, with a special attention on water bearing structures. We present the data as a series of Karous-Hjelt filtered profiles [Karous and Hjelt 1977], where the values correspond to apparent current densities at different depths which would generate a magnetic field equal to the measurements. Areas of current densities with values significantly greater or less than 0 correspond to good conductors, providing in some cases information on the dip angle and dip direction of structures. The VLF data clearly shows that highly conductive structures, such as a metallic water pipe (Figure 7, profile 1-1') have a strong effect on values. However, in terrains with no recognisable structures (right part of 1-1"profile), the VLF profiles show very little variation, confirming the low levels of signal expected in areas with no evidence 


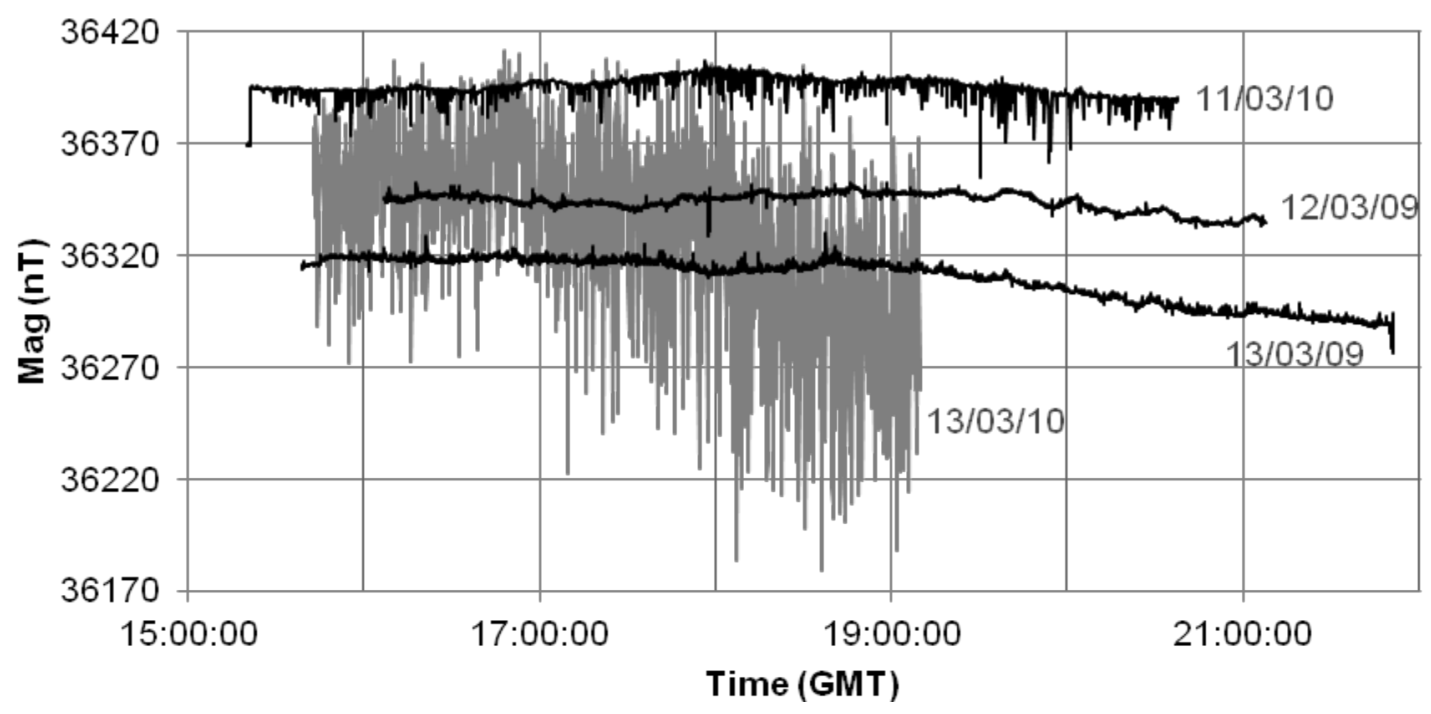

Figure 5: Record of magnetic diurnal variation on 4 different days in 2009 and 2010. Location: $12^{\circ} 00^{\prime} 02.65^{\prime \prime} \mathrm{N}$, $86^{\circ} 09^{\prime} 03.63^{\prime \prime} \mathrm{W}$ or $16 \mathrm{P} 5924231326777$.

of fault structures.

Both profiles 2-2' and 3-3' (Figure 7) cross areas where the ring structure is known to be present as evidenced by strong anomalies with a very well-defined dip direction; in profile 3-3', a double parallel structure consistent with ground observations has been detected. The orientation of the ring fracture for both profiles also corroborates the hypothesis that this is an inward dipping fracture system.

\subsection{InSAR}

Repeat pass satellite interferometric synthetic aperture radar (InSAR) uses time-separated radar images acquired from the same position in orbit to measure deformation of the Earth's surface with a precision of millimetres to centimetres [e.g. Massonnet and Feigl 1995; Massonnet and Feigl 1998]. Interferograms are maps of phase change, which in addition to surface displacements, also include phase contributions from changes to satellite viewing geometry, instrument thermal noise, scattering and dielectric properties of the ground, and the effects of tropospheric water vapour. In Central America, the highest magnitude 'nuisance factor' is generally the radar path delays associated with stratified water vapour [Ebmeier et al. 2013a]. A regional InSAR survey identified an area of slow subsidence $(1 \mathrm{~cm} / \mathrm{yr})$ at Masaya between 2007 and 2010 that was confined to the ring fracture [Ebmeier et al. 2013b]. We selected 11 ascending interferograms and 5 descending interferograms (Appendix 1: Table A2 and Supplementary Material in Stephens et al. [2017]). We constructed a time series from these interferograms spanning between October 2007 to June 2010 using a linear least squares inversion of phase for a network of interferograms [e.g. Lundgren et al. 2001], solving for velocity rather than displacement using a generalized inverse matrix and singular value decomposition [e.g. Berardino et al. 2002]. We explicitly assumed that the volcano was not deforming on the first acquisition date.

Although displacement is not necessarily distinguishable from atmospheric phase artefacts in individual interferograms, time series analysis of these data revealed a net subsidence that lasted at least until the end of 2009. This is illustrated by Figure 8, where the main panel shows both deformation and atmospheric signals (e.g. in the northwest of the caldera) distinguished using pairwise logic and time series analysis (Figure 8B). Subsidence appears to be limited to the southern section of the area bounded by the ring fault and bordered by Nindiri and Santiago craters to the South (Figure $8 \mathrm{~A}$ ). Parts of this region subsided by up to $4 \mathrm{~cm}$ between October 2007 and July 2010. Although the uncertainties associated with atmospheric path delays have not been corrected, we are confident that this signal captures surface displacements because (1) multiyear trends, as seen here, are not consistent with atmospheric processes, which are generally assumed to be uncorrelated at the sampling interval of SAR satellites and (2) displacement rates and spatial patterns are very similar for ascending and descending satellite geometries, for which atmospheric components are independent (see time series, Figure 8B). Furthermore, there is an abrupt drop in displacement rate at the location inferred for the ring fracture from the near-surface geophysical methods described above (see inset profile Figure 8A). The spatial extent of the 2007-10 subsidence is similar to that of the transient deformation detected during explosive eruptions in 2012 [Stephens et al. 2017]. It has sharper boundaries and is more spatially restricted than during more recent high magnitude uplift [Stephens and Wauthier 2018], which produced an $\sim 8 \mathrm{~cm}$ ground uplift centred within the ring fracture over a 15-month period (6 November 2015 

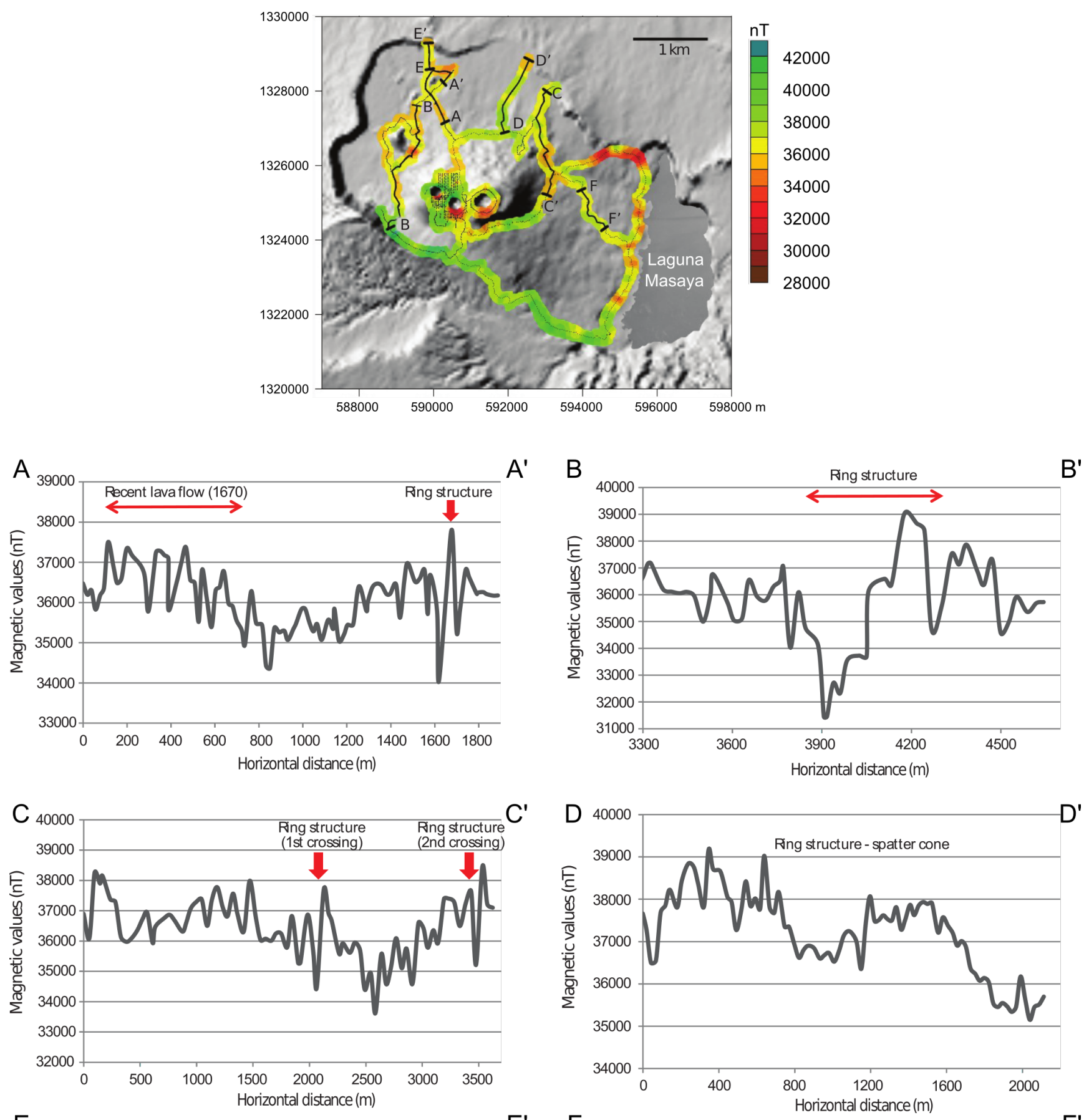

$E$

$E^{\prime} \quad F$
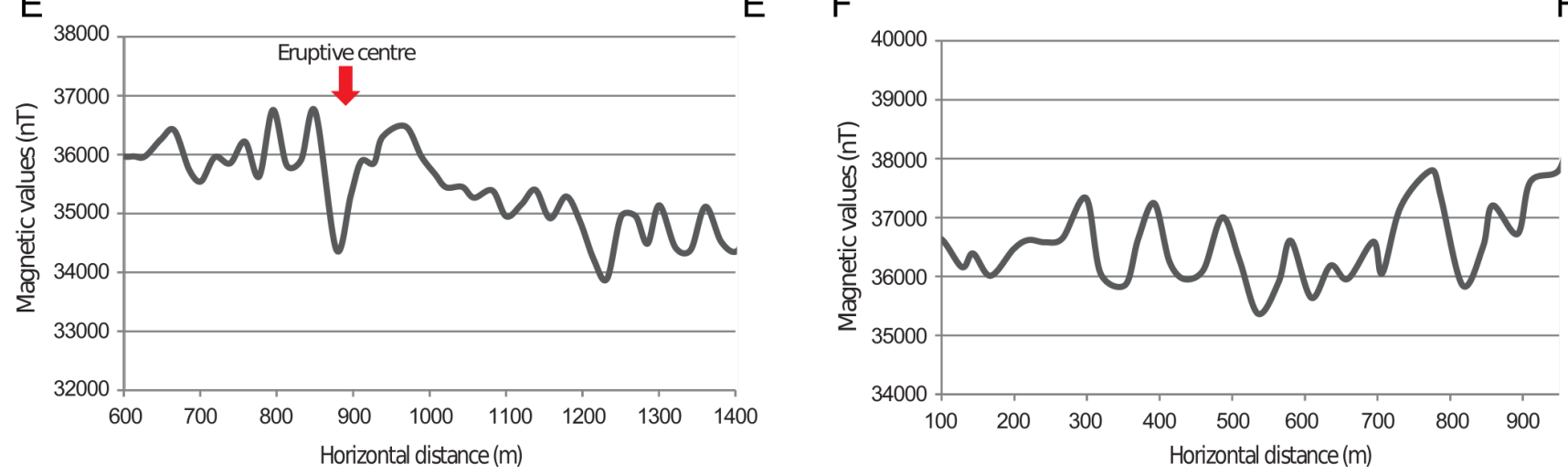

Figure 6: Observed total magnetic field anomalies and profiles on Masaya caldera. Red arrows indicate the proposed location of the ring fracture. While $[\mathrm{A}]$ to $[\mathrm{E}]$ profiles cross the suggested ring structure, profile $[\mathrm{F}]$ shows the normal background magnetic variation on the caldera floor (control profile). 


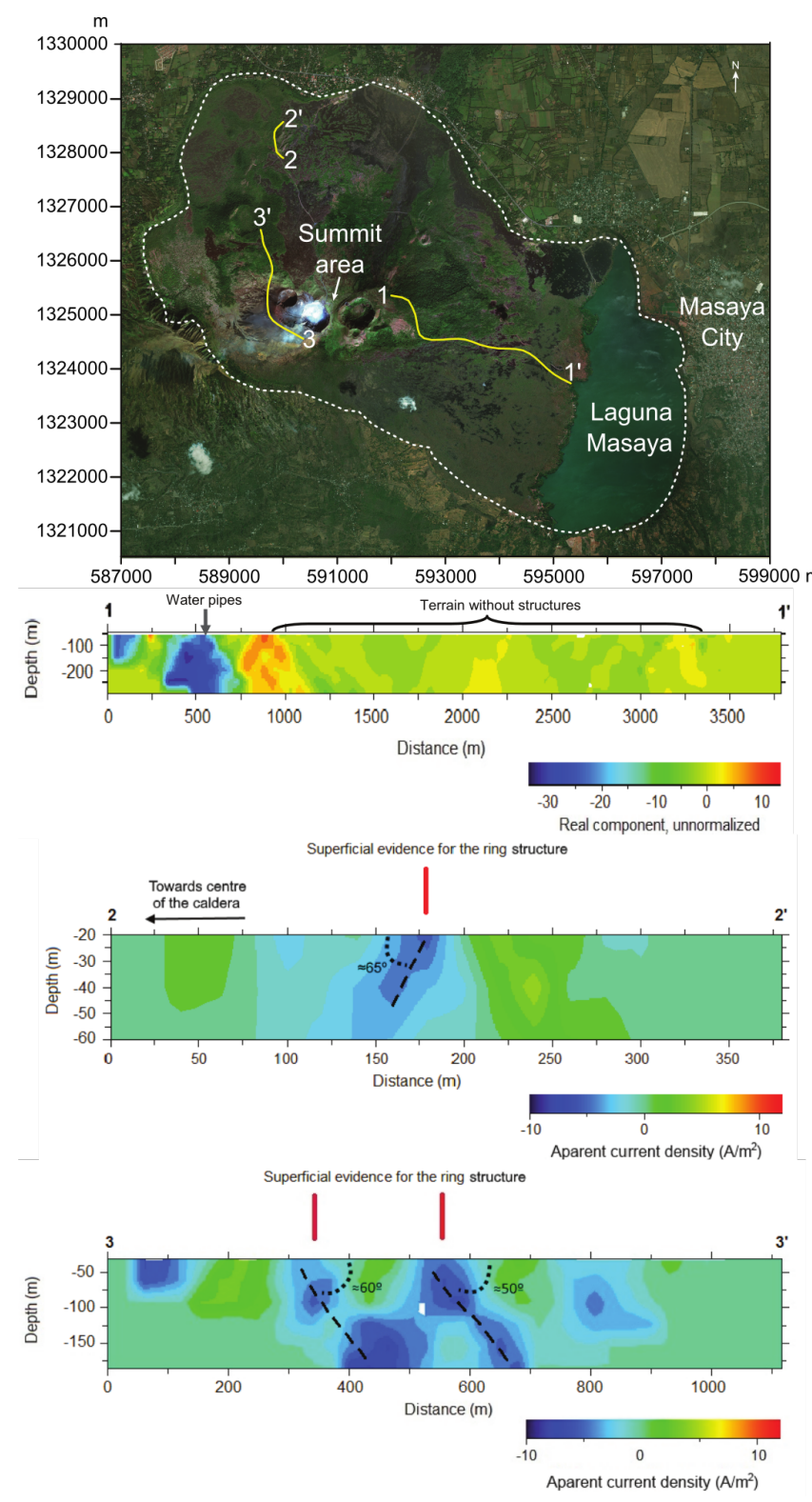

Figure 7: VLF profiles showing several artificial and natural features on the floor of Masaya caldera. A Karous-Hjelt filter was applied to the data [Karous and Hjelt 1977; Karous and Hjelt 1983]. Profile 1-1': Control profile showing effect of water pipes buried at 2 $\mathrm{m}$ depth (dipole centred at $750 \mathrm{~m}$ ) and terrain without evidence of shallow structures on Masaya Caldera's floor; 2-2': Single ring structure dips towards the central point of the caldera in depth (apparent dip: $\approx 65^{\circ}$ ); 3-3': Double ring structure dips inwards (apparent dip: $\left.50-60^{\circ}\right)$. Red lines mark locations of structures on the surface, and probable orientations at depth are shown with dashed black lines. The depth of penetration for each profile has been limited to the depth free of artifacts which could affect the geological interpretation.

to 1 September 2016); this period of uplift coincides roughly with the appearance of the new lava lake in November 2015. This uplift was also detected by preci- sion leveling within the caldera between 1993 and 2017 which detected inflation of $\sim 5.5 \mathrm{~cm}$ within the ring fracture in the period 2015-2017 [Murray et al. 2017; Rymer et al. 2017].

\section{Discussion}

\subsection{Ring structure}

\subsubsection{Geometry}

The geological and geophysical evidence presented in this study strongly supports the presence of an approximately circular structure within Masaya caldera (Figure 2). While the alignment of several of the features along the proposed outline of this structure was already known, the location of magnetic and VLF anomaliesas well as other newly mapped features-confirms this hypothesis. This $3.5 \mathrm{~km}$ diameter and $10 \mathrm{~km}^{2}$ circular structure can be considered continuous, since the features marking its presence can be found all along its perimeter. Along the northern edge of the structure, which had previously been only poorly mapped due to limited accessibility, several spatter cones and fractures have now been found. Although there are currently no unambiguous signs of active faulting, this evidence suggests that the inner floor may be entirely decoupled from the outer walls of the structure along the entire perimeter. However, the variation in subsidence rate within the ring fracture (Figure 8) suggest that the internal block is not a perfectly coherent single unit. The VLF data suggest that this ring fracture is an inward dipping structure; defining an incipient nested caldera within Masaya caldera.

An interpretation of the subsidence within the southern sector of the ring fracture invoking only magmatic processes would be consistent with other deformation studies at Masaya. The low magnitude transient displacements associated with explosive eruptions in April-May 2012 were attributed to magma accumulation at a constriction between 400 and $1200 \mathrm{~m}$ depth, modelled with the geometry of conduit surrounded by brecciated material [Stephens et al. 2017], while the $\sim 8$ $\mathrm{cm}$ uplift 2015-2016 is thought to be caused by magmatic processes centred within the ring fault [Stephens and Wauthier 2018]. The best-fit geodetic source for the 2015-16 uplift had a depth of $\sim 5 \mathrm{~km}$, consistent with the depth of $\sim 4.5 \mathrm{~km}$ estimated for melt inclusion entrapment in olivine crystals found in the cinder cones around the ring fracture [Zurek et al. 2019].

However, the fact that subsidence is consistently limited to within the bounds identified by the ring fault demonstrates a relationship between the faults, fissures and boundaries identified in this study and the geometry of magma storage. It is also possible that deformation caused by magmatic mechanisms (for example depressurisation linked to long term degassing, e.g. Stoiber et al. [1986]) is to some extent accommo- 
A
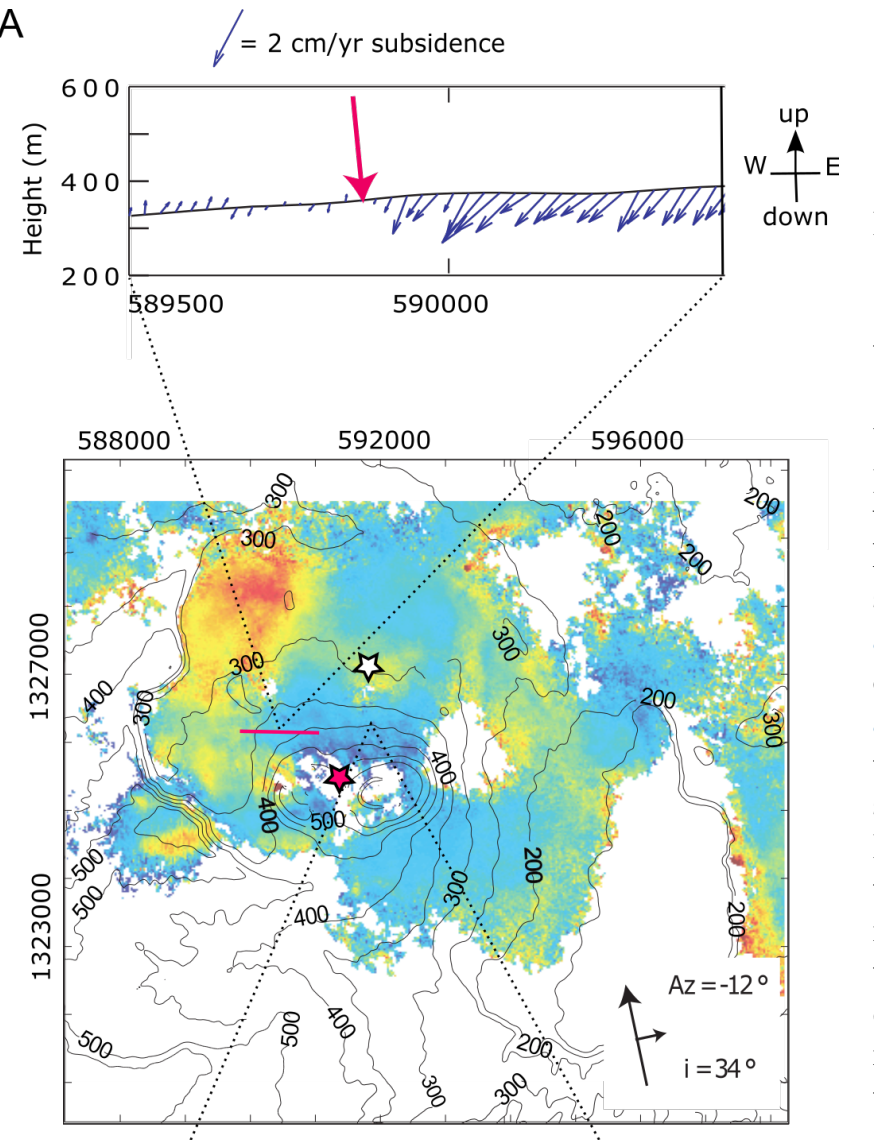

B

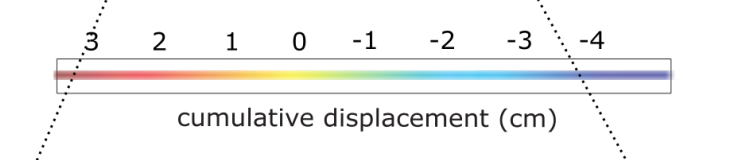

$B$

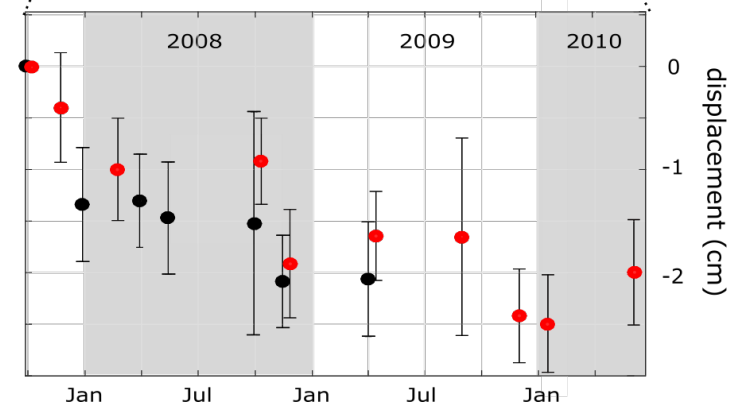

dated by displacement on ring faults in the shallow sub-surface.

While the VLF data seem to suggest an inward dipping ring system, the other geophysical data are less clear on this. It is usual to invoke outward dipping faults to accommodate caldera subsidence. However, a ring dyke or cone sheet intrusion could favour inward dipping features. Since the most recent Plinian activity was associated with phreatomagmatic activity, the ring system could even be considered to be reminiscent of a maar that transitions towards a caldera [Palladino et al. 2015; Palladino et al. 2017].
Figure 8: InSAR-measured total displacements between 10 October 2007 and 2 June 2010 from ALOS-1 imagery (central panel) shown relative to the average phase in the part of the interferogram outside Masaya's caldera (grid in UTM coordinates). Note that this individual interferogram includes representative atmospheric phase contributions as well as the phase changes that we attribute to subsidence. Contours show topographic height above sea level. The white star indicates the position of the best-fit spherical source found by Stephens and Wauthier [2018], and the pink star shows the location of the conduit source proposed by Stephens et al. [2017]. The spatial extent of the transient deformation identified by Stephens et al. [2017] during explosive eruptions in 2012 is indicated by a dashed pink line. The inset profile [A] uses blue arrow size to show total cumulative displacement (derived from ascending track), while directions indicate the sense of motion found from inversion of a pair of ascending and descending interferograms (assuming that north-south motion captured in interferograms is negligible; uncertainties in direction are expected to be of the order of 20 degrees). A pink arrow marks the inferred location of the ring fracture from other geophysical methods. The inset time series [B] is constructed from both ascending (red circles) and descending (black circles) images. Random noise of mean magnitude $1 \mathrm{~cm}$ was added to every pixel before inversion, neglecting the effects of spatial correlation. Error bars show the standard deviations for 100 Monte Carlo repetitions. Figure adapted from the Supplementary material presented by Stephens et al. [2017].

\subsubsection{Relation to activity in time}

The present shape and characteristics of Masaya caldera's morphology, including the structural framework and the existing volcanic constructs, is the product of the evolution of the caldera system after the last Plinian eruption ( $1.8 \mathrm{ka}, 10 \mathrm{~km}^{3}$ erupted; Pérez Fernández [2007]); this set the conditions for the development of the inner caldera.

The emptying of the magma chamber caused by this eruption, and the subsequent additional subsidence associated with it is the most probable reason for the generation of the ring fracture [Kutterolf et al. 2007]. Following the last Plinian eruption, an estimated 14.2 $\mathrm{km}^{3}$ [Williams 1983a] of lava flows and ash have been 
erupted and deposited on the caldera floor. Since the source vents for most of these eruptions (except for SC3 and SC4, Figure 2) can be found along the ring fracture (Figure 2), we can conclude that this circular structure has controlled the nature and location of eruptive activity within the caldera for the past $1.8 \mathrm{ka}$. The fact that all active fumarolic fields, sources of recent lava emissions, subsidence, and most cinder cones are organized around the ring fracture also suggests that this structure will very likely continue to play a fundamental role in determining the location of most mid to longterm volcanic phenomena on the caldera floor.

Given the relatively central location of this feature within the caldera, low energy explosive or effusive activity will very rarely affect areas outside the caldera boundaries. However, the presence of several densely populated communities (Masaya, Nindiri, Ticuantepe, La Concepción, Masatepe) with 500,000 inhabitants around these boundaries (coinciding with the administrative limits of Masaya Volcano National Park), has obvious implications for hazard assessment in the area. There is a high probability that the most important threat that local communities in the area will continue to face in the short term is the persistent degassing coming from Santiago crater. Continuous release of pressure and energy through degassing and minor explosive activity at Masaya's open vents, may decrease the likelihood of major explosive activity resuming.

It is also important to note that the rate of juvenile magma emission since the last Plinian eruption $(1.8 \mathrm{ka})$ has dropped considerably. Although lava flows have erupted and covered the caldera floor entirely, building all the major volcanic centres existing today, of the $14.2 \mathrm{~km}^{3}$ estimated erupted volume [Williams 1983a] only a small portion has been erupted in recent times. For the last $\sim 350$ years, several ephemeral lava lakes have formed at the bottom of the pit craters, and at least five gas emission crises have degassed approximately $67 \mathrm{~km}^{3}$ of basaltic magma $\left(\sim 0.19 \mathrm{~km}^{3} / \mathrm{yr}\right.$; Zurek et al. [2019]. However, during this period, only two lava flows have been emitted (1670 flow, $2.12 \mathrm{~km}^{2}$ area, $\sim 10.6 \times 10^{6} \mathrm{~m}^{3}$; 1772 flow, $7.51 \mathrm{~km}^{2}, \sim 22.5 \times 10^{6} \mathrm{~m}^{3}$; Williams [1983a]). Far more magma has degassed during this period than has erupted and this suggests an efficient process of magma convection at shallow depth [Rymer et al. 1998].

This limited recent eruptive activity may be due to a combination of effective emptying of the magma chamber through the emission of lava flows following the Plinian eruption, and establishment of an efficiently convecting shallow plumbing system as evidenced by the persistent degassing [e.g. Williams-Jones et al. 2003; Stix 2007] and periodic formation of lava lakes within Masaya's open vent. Longer observation periods will be required to determine if the vertical movement of the inner caldera block is an important factor in controlling the cyclicity of eruptive periods.

\subsection{Cofradías fault and related structures}

\subsubsection{Geometry}

Being part of the Managua graben, this deep-seated fault is probably one of the primary factors for the development of the caldera. The expression of this fault on the caldera floor is noticeable in two different locations: 1) A NNE-SSW eruptive fissure that runs Northwards from San Fernando Crater (Figure 2, LF2) and appears genetically related (similar geological characteristics and spatial orientation) to an $8-10 \mathrm{~m}$ fissure South of San Fernando crater (Figure 2, LF3), and several volcanic centres (spatter cones) distributed along it. 2) The second family of fractures within the fissure field in the North part of the caldera (Figure 4). The chaotic and young nature of the terrain complicates identification of fracture families here; however, the N$S$ running set is one of the clearest sets of fractures. From its orientation and position compared to the other sets, it is also likely to be related to the graben-limiting Cofradías fault [Williams 1983a].

\subsubsection{Relation to activity in time}

The graben fracture is the source for the last recorded lava flow on the caldera floor (1772). Thus, we suggest that present volcanic activity in the caldera is favoured by the continued development of the pull-apart basin, and, in particular, by the extensional activity generated by the sinistral Cofradías fault [van Wyk de Vries 1993]. Aside from the 1772 fissure eruption, at least two of the active fumarolic centres on the caldera floor (F4 and F5) are found along this fracture, suggesting it is one of the main centres of activity within the caldera. Indeed, it has been suggested that the Managua Graben has developed as a consequence of the weak magmatic intrusion under Las Sierras-Masaya caldera [van Wyk de Vries 1993] and therefore that there is an ongoing risk of volcanism in the entire caldera-graben area.

\subsection{Hydrothermal system}

Masaya's hydrothermal system has been well studied [e.g. MacNeil et al. 2007; Mauri et al. 2010; Mauri et al. 2012] and is also structurally-controlled given that all the active degassing manifestations can be found in areas where important underground discontinuities are evident on the surface (F2-F3). Furthermore, the structural survey clearly shows that they are coincident with the ring fracture or with the large fissure that is the expression of the Cofradías fault within the caldera (including sites F1, F4, F5, F6 and F7). Diffuse degassing structures detected by measuring soil $\mathrm{CO}_{2}$ concentration anomalies and uprising hydrothermal fluids mapped with self-potential methods also show a good spatial correlation with the structures mentioned above [St-Amand 1999; Pearson 2010; Mauri et al. 2012]. The 
high degree of stability over more than 20 years of the emissions in at least three of the fumarolic sites (F1-F4-F7) supports the long-term existence of a stable hydrothermal system on Masaya Caldera that exploits lateral discontinuities provided by large structures such as the ring fracture. This results in the structural framework playing a pivotal role in dissipating the excess heat and pressure generated by successive injections of magma to the shallower plumbing system of the caldera, keeping it in a steady state free of major eruptive activity for at least the last 240 years. This long-term stability suggests also that the circulation of fluids themselves act to keep this communication path open. The intermittent appearance of the other 4 emission sites (F2-F3-F5-F6) likely relates to fluctuations in the hydrothermal system caused by rainfall and heat flux variations.

\section{Conclusions}

While there are currently no unequivocal signs of active faulting, the morphology and characteristics of the ring fracture identified here define it as a caldera-limiting structure in itself. It therefore follows that the Las Sierras-Masaya volcanic complex is composed of a series of nested calderas, the smallest of which is delimited by the ring fracture. Two main structural features control the stress regime in the area of Masaya Volcano. The first is the inner caldera collapse, limited by the ring fracture and a consequence of the emptying of the magma chamber following the last Plinian eruption $(1.8 \mathrm{ka})$. The second is the extensional regime represented by the manifestation of the Cofradias fault (the eastern limiting fault of the Managua graben) within the caldera. Both structures play a major role in the style and location of volcanic activity at Masaya volcano, and their geometry should be taken into consideration for the future elaboration of hazard maps. The caldera defined by the ring fracture is the site of all volcanic activity and is expected to be the focus for future activity. Monitoring efforts should be focussed on deformation within this caldera (rather than broadly across the whole Masaya caldera or localised just at the currently active vent). The mobility of the caldera blocks suggests that there would be a surface manifestation of sub-surface magmatic pressure changes and so precursors to significant changes in activity would be measurable. This work has benefitted from interdisciplinary studies. It is unusual, but as shown here instructive, to combine VLF with InSAR and it is recommended that future studies aim to integrate several geophysical methodologies with geological survey work to identify both active and static structures.

\section{ACKNOWledgements}

We would like to thank staff at the Instituto Nicaragüense de Estudios Territoriales (INETER) for their continued support. We also thank Carlos Molina Palma and his family, Sergio Rocha and María Tamariz, and all the staff of the Parque Nacional Volcán Masaya, without whom this work would not have been possible. Fieldwork was facilitated by the help of all the volunteers of the 2009, 2010 and 2011 Earthwatch Expedition: Volcano. We appreciate the thorough reviews by Ben van Wyk de Vries and an anonymous reviewer. This work was supported by The Open University (UK), Santander UK, the Earthwatch Institute and NSERC Discovery. SKE acknowledges support from The Leverhulme Trust and the European Space Agency and the Centre for the Modelling of Earthquakes, Volcanoes Tectonics (COMET). ALOS-PALSAR data have previously been described in Ebmeier et al. [2013] and were acquired through the WInSAR programme, made available by the Alaska Satellite Facility (ASF) and are copyright of the Japanese Space Agency (JAXA).

\section{Author CONTRibutions}

The project was conceived by GCG, HR, SB and GWJ. GCG and JZ completed the detailed structural and geophysical surveys. The InSAR methodology and analysis was completed by SE. GCG, SE and GWJ generated all figures. All authors contributed to the discussion, data interpretation and writing of the paper.

\section{Data AVailability}

The geophysical data and extensive geological field notes are available in the PhD thesis of GCG. This is available at https://ethos.bl.uk/OrderDetails.do?uin=uk.bl.ethos.664474.

\section{COPYRIGHT NOTICE}

(C) The Author(s) 2019. This article is distributed under the terms of the Creative Commons Attribution 4.0 International License, which permits unrestricted use, distribution, and reproduction in any medium, provided you give appropriate credit to the original author(s) and the source, provide a link to the Creative Commons license, and indicate if changes were made.

\section{REFERENCES}

Aiuppa, A. et al. (2018). "Tracking Formation of a Lava Lake From Ground and Space: Masaya Volcano (Nicaragua), 2014-2017". Geochemistry, Geophysics, Geosystems 19.2, pp. 496-515. DoI: 10.1002/ $2017 \mathrm{gc} 007227$. 
St-Amand, K. (1999). "The Distribution and Origin of Radon, $\mathrm{CO}_{2}$ and $\mathrm{SO}_{2}$ Gases and Multifractal Behaviour of $\mathrm{SO}_{2}$ at Masaya Volcano, Nicaragua". PhD thesis. Université de Montreal, Canada.

Anderson, S., E. Stofan, S. Smrekar, J. Guest, and B. Wood (1999). "Pulsed inflation of pahoehoe lava flows: implications for flood basalt emplacement". Earth and Planetary Science Letters 168.1-2, pp. 7-18. DoI: 10. 1016/s0012-821x(99)00044-8.

Berardino, P., G. Fornaro, R. Lanari, and E. Sansosti (2002). "A new algorithm for surface deformation monitoring based on small baseline differential SAR interferograms". IEEE Transactions on Geoscience and Remote Sensing 40.11, pp. 2375-2383. Dor: 10.1109/ tgrs.2002.803792.

Bice, D. C. (1980). "Tephra stratigraphy and physical aspects of recent volcanism near Managua". PhD thesis. Berkely, USA: University of California.

Bonvalot, S., J. Métaxian, G. Gabalda, and O. Pérez (1995). "Gravity and GPS studies at Masaya Volcano (Nicaragua): Structural modelling and monitoring volcanic activity". IUGG XIX meeting. Boulder, Colorado, USA.

Branan, Y. K., A. Harris, I. M. Watson, J. Phillips, K. Horton, G. Williams-Jones, and H. Garbeil (2008). "Investigation of at-vent dynamics and dilution using thermal infrared radiometers at Masaya volcano, Nicaragua". Journal of Volcanology and Geothermal Research 169.1-2, pp. 34-47. Dor: $10.1016 / \mathrm{j}$. jvolgeores.2007.07.021.

Burton, M. R., C. Oppenheimer, L. A. Horrocks, and P. W. Francis (2000). "Remote sensing of CO2 and $\mathrm{H} 2 \mathrm{O}$ emission rates from Masaya volcano, Nicaragua". Geology 28.10, p. 915. DoI: $10.1130 /$ 0091-7613(2000) 28<915: rsocah>2. 0 . co;2.

Caravantes Gonzalez, G. (2013). "Geophysical constraints on the structural evolution and hazards of Masaya volcano, Nicaragua". PhD thesis. Open University.

Chiodini, G. (2005). "Carbon dioxide diffuse degassing and estimation of heat release from volcanic and hydrothermal systems". Journal of Geophysical Research 110.B8. Dor: $10.1029 / 2004$ jb003542.

Chitwood, L. (1994). "Inflated basaltic lava-Examples of processes and landforms from central and southeast Oregon". Oregon Geology 56.1, pp. 11-21.

Cole, J., D. Milner, and K. Spinks (2005). "Calderas and caldera structures: a review". Earth-Science Reviews 69.1-2, pp. 1-26. DoI: 10.1016/ j . earscirev. 2004. 06.004.

Connor, C. and S. Williams (1989). "Interpretation of gravity anomalies, Masaya caldera complex, Nicaragua". Transactions of the 12th Caribbean Conference, St. Croix, US Virgin Islands: Miami, Florida, Miami Geological Society, pp. 495-502.

Connor, C. B., S. Lane-Magsino, J. A. Stamatakos, R. H. Martin, P. C. LaFemina, B. E. Hill, and S. Lieber (1997). "Magnetic surveys help reassess volcanic haz- ards at Yucca Mountain, Nevada". Eos, Transactions American Geophysical Union 78.7, p. 73. DoI: 10 . 1029/97eo00049.

Costantini, L., C. Bonadonna, B. F. Houghton, and H. Wehrmann (2009). "New physical characterization of the Fontana Lapilli basaltic Plinian eruption, Nicaragua". Bulletin of Volcanology 71.3, pp. 337355. Dor: 10.1007/s00445-008-0227-9.

Crenshaw, W. B., S. N. Williams, and R. E. Stoiber (1982). "Fault location by radon and mercury detection at an active volcano in Nicaragua". Nature 300.5890, pp. 345-346. DoI: 10. 1038/300345a0.

Duffell, H. J., C. Oppenheimer, D. M. Pyle, B. Galle, A. J. McGonigle, and M. R. Burton (2003). "Changes in gas composition prior to a minor explosive eruption at Masaya volcano, Nicaragua". Journal of Volcanology and Geothermal Research 126.3-4, pp. 327-339. Dor: 10.1016/s0377-0273 (03)00156-2.

Ebmeier, S. K., J. Biggs, T. A. Mather, and F. Amelung (2013a). "Applicability of InSAR to tropical volcanoes: insights from Central America". Geological Society, London, Special Publications 380.1, pp. 15-37. Dor: 10.1144/sp380.2.

- (2013b). "On the lack of InSAR observations of magmatic deformation at Central American volcanoes". Journal of Geophysical Research: Solid Earth 118.5, pp. 2571-2585. Dor: 10.1002/ jgrb. 50195.

Erenler, H. E., M. C. Orr, M. P. Gillman, B. R. B. Parkes, H. Rymer, and J.-M. Maes (2016). "Persistent nesting byAnthophoraLatreille, 1803 (Hymenoptera: Apidae) bees in ash adjacent to an active volcano". PanPacific Entomologist 92.2, pp. 67-78. Dor: $10.3956 /$ 2016-92.2.67.

Girard, G. and B. van Wyk de Vries (2005). "The Managua Graben and Las Sierras-Masaya volcanic complex (Nicaragua) pull-apart localization by an intrusive complex: results from analogue modeling". Journal of Volcanology and Geothermal Research 144.1-4, pp. 37-57. Dor: 10.1016/ j . jvolgeores . 2004 . 11. 016.

Harris, A. J. L. (2009). "The pit-craters and pit-craterfilling lavas of Masaya volcano". Bulletin of Volcanology 71.5, pp. 541-558. DoI: 10 . 1007 / s00445- 008 $0241-y$.

Hon, K., J. Kauahikaua, R. Denlinger, and K. Mackay (1994). "Emplacement and inflation of pahoehoe sheet flows: Observations and measurements of active lava flows on Kilauea Volcano, Hawaii". Geological Society of America Bulletin 106.3, pp. 351-370. Dor: 10 . 1130/0016-7606(1994) 106<0351: eaiops>2 . 3 . co; 2 .

Karous, M. and S. E. Hjelt (1983). "Linear filtering of VLF dip-angle measurements". Geophysical Prospecting 31.5, pp. 782-794. DoI: 10.1111/ j . 1365-2478. 1983. tb01085.x.

Karous, M. and S. E. Hjelt (1977). Determination of apparent current density from VLF measurements. University of Oulu Oulu. 
Kutterolf, S., A. Freundt, W. Peréz, T. Mörz, U. Schacht, H. Wehrmann, and H.-U. Schmincke (2008). "Pacific offshore record of plinian arc volcanism in Central America: 1. Along-arc correlations". Geochemistry, Geophysics, Geosystems 9.2. DoI: 10 . 1029 / 2007 gc001631.

Kutterolf, S., A. Freundt, W. Pérez, H. Wehrmann, and H.-U. Schmincke (2007). "Late Pleistocene to Holocene temporal succession and magnitudes of highly-explosive volcanic eruptions in west-central Nicaragua". Journal of Volcanology and Geothermal Research 163.1-4, pp. 55-82. DoI: 10 . 1016 / j . jvolgeores.2007.02.006.

La Femina, P. C., C. B. Connor, J. A. Stamatakos, and D. A. Farrell (2002). "Imaging an Active Normal Fault in Alluvium by High-Resolution Magnetic and Electromagnetic Surveys". Environmental E Engineering Geoscience 8.3, pp. 193-207. Dor: 10.2113/8.3 . 193.

Lehto, H. L. (2007). "Self-Potential Anomalies and CO2 Flux on Active Volcanoes: Insights from Time and Spatial Series at Masaya, Telica, and Cerro Negro, Nicaragua”. MA thesis. University of South Florida, USA.

Lewicki, J. L., C. Connor, K. St-Amand, J. Stix, and W. Spinner (2003). "Self-potential, soil CO2flux, and temperature on Masaya volcano, Nicaragua". Geophysical Research Letters 30.15. DoI: 10 . 1029 / $2003 \mathrm{gl} 017731$.

Lewicki, J. L., D. Bergfeld, C. Cardellini, G. Chiodini, D. Granieri, N. Varley, and C. Werner (2005). "Comparative soil CO2 flux measurements and geostatistical estimation methods on Masaya volcano, Nicaragua". Bulletin of Volcanology 68.1, pp. 76-90. DoI: 10.1007 / s00445-005-0423-9.

Locke, C. A., H. Rymer, and J. Cassidy (2003). "Magma transfer processes at persistently active volcanoes: insights from gravity observations". Journal of Volcanology and Geothermal Research 127.1-2, pp. 73-86. Dor: 10.1016/s0377-0273(03)00179-3.

Lopez-Loera, H., J. Urrutia-Fucugauchi, and L. M. AlvaValdivia (2010). "Magnetic characteristics of fracture zones and constraints on the subsurface structure of the Colima Volcanic Complex, western Mexico". Geosphere 6.1, pp. 35-46. Dor: 10.1130/ges00204 . 1.

Lundgren, P., S. Usai, E. Sansosti, R. Lanari, M. Tesauro, G. Fornaro, and P. Berardino (2001). "Modeling surface deformation observed with synthetic aperture radar interferometry at Campi Flegrei caldera". Journal of Geophysical Research: Solid Earth 106.B9, pp. 19355-19366. DoI: 10.1029/2001 jb000194.

MacNeil, R. E., W. E. Sanford, C. B. Connor, S. K. Sandberg, and M. Diez (2007). "Investigation of the groundwater system at Masaya Caldera, Nicaragua, using transient electromagnetics and numerical simulation". Journal of Volcanology and Geothermal Research 166.3-4, pp. 217-232. DoI: $10.1016 / \mathrm{j}$. jvolgeores .2007.07.016.
MacNeil, R. E. (2006). "Geophysical Investigations and Groundwater Modeling of the Hydrologic Conditions at Masaya Caldera, Nicaragua". MA thesis. University of South Florida, USA.

Massonnet, D. and K. L. Feigl (1995). "Discrimination of geophysical phenomena in satellite radar interferograms". Geophysical Research Letters 22.12, pp. 1537-1540. DoI: 10.1029/95gl00711.

- (1998). "Radar interferometry and its application to changes in the Earth's surface". Reviews of Geophysics 36.4, pp. 441-500. DoI: 10. 1029/97rg03139.

Mather, T., D. Pyle, V. Tsanev, A. McGonigle, C. Oppenheimer, and A. Allen (2006). "A reassessment of current volcanic emissions from the Central American arc with specific examples from Nicaragua". Journal of Volcanology and Geothermal Research 149.3-4, pp. 297-311. DoI: 10.1016/ j . jvolgeores . 2005 . 07.021.

Mauri, G., G. Williams-Jones, and G. Saracco (2010). "Depth determinations of shallow hydrothermal systems by self-potential and multi-scale wavelet tomography". Journal of Volcanology and Geothermal Research 191.3-4, pp. 233-244. Dor: 10 . 1016 / j . jvolgeores.2010.02.004.

Mauri, G., G. Williams-Jones, G. Saracco, and J. M. Zurek (2012). "A geochemical and geophysical investigation of the hydrothermal complex of Masaya volcano, Nicaragua". Journal of Volcanology and Geothermal Research 227-228, pp. 15-31. Dor: 10 . 1016 / j . jvolgeores.2012.02.003.

McBirney, A. R. (1956). "The Nicaraguan volcano Masaya and its caldera". Transactions, American Geophysical Union 37.1, p. 83. Dor: 10 . 1029 / tr037i001p00083.

Métaxian, J.-P. (1994). "Etude sismologique et gravimétrique d'un volcan actif: dynamisme interne et structure de la Caldeira Masaya, Nicaragua". PhD thesis. Université Savoie Mont Blanc, France.

Métaxian, J.-P., P. Lesage, and J. Dorel (1997). "Permanent tremor of Masaya Volcano, Nicaragua: Wave field analysis and source location". Journal of Geophysical Research: Solid Earth 102.B10, pp. 2252922545. DoI: $10.1029 / 97$ jb01141.

Moune, S., F. Faure, P.-J. Gauthier, and K. W. Sims (2007). "Pele's hairs and tears: Natural probe of volcanic plume". Journal of Volcanology and Geothermal Research 164.4, pp. 244-253. DoI: 10 . $1016 /$ j . jvolgeores.2007.05.007.

Murray, J., G. Caravantes-Gonzales, H. Rymer, W. G, and F. Ferrucci (2017). "Recent inflation at Masaya volcano, Nicaragua". IAVCEI 2017 Scientific Assembly. Portland, Oregon, USA.

Nadeau, P. A. and G. Williams-Jones (2009). "Apparent downwind depletion of volcanic SO2 flux-lessons from Masaya Volcano, Nicaragua". Bulletin of Volcanology 71.4, pp. 389-400. DOI: 10 . 1007 / s00445008-0251-9. 
Al-Oufi, A., H. A. Mustafa, E. Al-Tarazi, and J. A. Rajab (2008). "Exploration of the extension of two lava tubes, faults and dikes using very low frequencyelectromagnetic technique in NE Jordan". Acta Geophysica 56.2, pp. 466-484. DoI: 10 . 2478 / s11600 008-0009-y.

Padilla, G. D. et al. (2014). "Anomalous Diffuse CO2 Emissions at the Masaya Volcano (Nicaragua) Related to Seismic-Volcanic Unrest". Pure and Applied Geophysics 171.8, pp. 1791-1804. DOI: 10.1007/s00024013-0756-9.

Palladino, D. M., G. A. Valentine, G. Sottili, and J. Taddeucci (2015). "Maars to calderas: end-members on a spectrum of explosive volcanic depressions". Frontiers in Earth Science 3. DoI: 10.3389/feart. 2015. 00036.

- (2017). "Corrigendum: Maars to calderas: endmembers on a spectrum of explosive volcanic depressions". Frontiers in Earth Science 5. DoI: 10.3389 / feart.2017.00042.

Pearson, S. C. P., K. Kiyosugi, H. L. Lehto, J. A. Saballos, C. B. Connor, and W. E. Sanford (2012). "Integrated geophysical and hydrothermal models of flank degassing and fluid flow at Masaya volcano, Nicaragua”. Geochemistry Geophysics Geosystems 13. DOI: $10.1029 / 2012 \mathrm{gc004117.}$

Pearson, S., C. Connor, and W. Sanford (2008). "Rapid response of a hydrologic system to volcanic activity: Masaya volcano, Nicaragua”. Geology 36.12, p. 951. DoI: $10.1130 / \mathrm{g} 25210 \mathrm{a} .1$.

Pearson, S. C. (2010). "Diffuse degassing and the hydrothermal system at Masaya volcano, Nicaragua". PhD thesis. University of South Florida, USA.

Pérez Fernández, W. (2007). "Basaltic Plinian and violent Surtseyan eruptions from the Masaya Caldera Complex, Nicaragua". PhD thesis. ChristianAlbrechts Universität Kiel, Germany.

Pérez, W., A. Freundt, S. Kutterolf, and H.-U. Schmincke (2009). "The Masaya Triple Layer: A 2100 year old basaltic multi-episodic Plinian eruption from the Masaya Caldera Complex (Nicaragua)". Journal of Volcanology and Geothermal Research 179.34, pp. 191-205. DoI: 10.1016/ j . jvolgeores. 2008. 10.015.

Pérez, W. and A. Freundt (2006). "The youngest highly explosive basaltic eruptions from Masaya Caldera (Nicaragua): Stratigraphy and hazard assessment". Volcanic Hazards in Central America. Geological Society of America. DoI: 10.1130/2006.2412(10).

Pering, T. D., T. Ilanko, T. C. Wilkes, R. A. England, S. R. Silcock, L. R. Stanger, J. R. Willmott, R. G. Bryant, and A. J. S. McGonigle (2019). "A Rapidly Convecting Lava Lake at Masaya Volcano, Nicaragua". Frontiers in Earth Science 6. Dor: 10.3389 / feart . 2018. 00241.

Pezzo, E. D., F. Bianco, and G. Saccorotti (2001). "Separation of intrinsic and scattering $Q$ for volcanic tremor: An application to Etna and Masaya volca- noes". Geophysical Research Letters 28.16, pp. 30833086. Dor: $10.1029 / 2001 \mathrm{gl013372.}$

Roche, O., B. van Wyk de Vries, and T. Druitt (2001). "Sub-surface structures and collapse mechanisms of summit pit craters". Journal of Volcanology and Geothermal Research 105.1-2, pp. 1-18. Dor: 10.1016/ s0377-0273(00)00248-1.

Rossi, M. and A. Gudmundsson (1996). "The morphology and formation of flow-lobe tumuli on Icelandic shield volcanoes". Journal of Volcanology and Geothermal Research 72.3-4, pp. 291-308. Dor: 10.1016/ 0377-0273(96)00014-5.

Rymer, H., G. Williams-Jones, J. Murray, P. Delmelle, K. Reid, and G. Caravantes Gonzalez (2017). "Precursors to the current activity at Masaya volcano, Nicaragua". IAVCEI 2017 Scientific Assembly. Portland, Oregon, USA.

Rymer, H., B. van Wyk de Vries, J. Stix, and G. WilliamsJones (1998). "Pit crater structure and processes governing persistent activity at Masaya Volcano, Nicaragua". Bulletin of Volcanology 59.5, pp. 345355. DOI: 10.1007 / s004450050196.

Sebesta, J. (1997). "Dynamic development of the relief in the Managua area, Nicaragua". Acta Universitatis Carolinae Geographica 2, pp. 93-109.

Stamatakos, J., C. Connor, and R. Martin (1997). “Quaternary Basin Evolution and Basaltic Volcanism of Crater Flat, Nevada, From Detailed Ground Magnetic Surveys of the Little Cones". The Journal of Geology 105.3, pp. 319-330. DoI: 10. 1086/515926.

Stephens, K. J. and C. Wauthier (2018). "Satellite Geodesy Captures Offset Magma Supply Associated With Lava Lake Appearance at Masaya Volcano, Nicaragua". Geophysical Research Letters 45.6, pp. 2669-2678. Dor: 10.1002/2017gl076769.

Stephens, K., S. Ebmeier, N. Young, and J. Biggs (2017). "Transient deformation associated with explosive eruption measured at Masaya volcano (Nicaragua) using Interferometric Synthetic Aperture Radar". Journal of Volcanology and Geothermal Research 344, pp. 212-223. Dor: 10.1016/ j . jvolgeores.2017.05. 014.

Stix, J. (2007). "Stability and instability of quiescently active volcanoes: The case of Masaya, Nicaragua". Geology 35.6, p. 535. Dor: 10.1130/g23198a. 1.

Stix, J., J. M. de Moor, J. Rüdiger, A. Alan, E. Corrales, F. D’Arcy, J. A. Diaz, and M. Liotta (2018). "Using Drones and Miniaturized Instrumentation to Study Degassing at Turrialba and Masaya Volcanoes, Central America". Journal of Geophysical Research: Solid Earth. Dor: 10.1029/2018 jb015655.

Stoiber, R. E., S. N. Williams, and B. J. Huebert (1986). "Sulfur and halogen gases at Masaya Caldera Complex, Nicaragua: Total flux and variations with time". Journal of Geophysical Research: Solid Earth 91.B12, pp. 12215-12231. Dor: 10. 1029/ jb091ib12p12215. 
van Wyk de Vries, B. (1993). “Tectonics and magma evolution of Nicaraguan volcanic systems". PhD thesis. The Open University, UK.

Viramonte, J. G. (1972). “Algunos volcanes Cuaternarios de la costa Pacífica de Nicaragua: Su composición, estructura, evolución y actividad". PhD thesis. Universidad Nacional de Córdoba, Argentina.

Walker, G. P. L. (1991). "Structure, and origin by injection of lava under surface crust, of tumuli, "lava rises", "lava-rise pits", and "lava-inflation clefts" in Hawaii”. Bulletin of Volcanology 53.7, pp. 546-558. Dor: 10.1007 / bf00298155.

Wehrmann, H., C. Bonadonna, A. Freundt, B. F. Houghton, and S. Kutterolf (2006). "Fontana Tephra: A basaltic Plinian eruption in Nicaragua". Volcanic Hazards in Central America. Geological Society of America. Dor: 10.1130/2006.2412(11).

Williams-Jones, G., H. Rymer, and D. A. Rothery (2003). "Gravity changes and passive SO2 degassing at the Masaya caldera complex, Nicaragua". Journal of Volcanology and Geothermal Research 123.1-2, pp. 137-160. DoI: 10 . 1016/s0377-0273 ( 03 ) 000337.

Williams, S. (1983a). "Geology and eruptive mechanisms of Masaya caldera complex". PhD thesis. Darmouth College, New Hampshire, USA.

Williams, S. N. (1983b). "Plinian airfall deposits of basaltic composition". Geology 11.4, p. 211. Dor: 10. 1130/0091-7613 (1983) 11<211: padobc>2 . 0 . co;2.
Witt, M. L. I., T. A. Mather, D. M. Pyle, A. Aiuppa, E. Bagnato, and V. I. Tsanev (2008). "Mercury and halogen emissions from Masaya and Telica volcanoes, Nicaragua". Journal of Geophysical Research 113.B6. DoI: $10.1029 / 2007$ jb005401.

Zablocki, C. J. (1978). "Applications of the VLF induction method for studying some volcanic processes of Kilauea volcano, Hawaii". Journal of Volcanology and Geothermal Research 3.1-2, pp. 155-195. Dor: 10 . 1016/0377-0273(78)90008-2.

Zlotnicki, J., G. Vargemezis, A. Mille, F. Bruère, and G. Hammouya (2006). "State of the hydrothermal activity of Soufrière of Guadeloupe volcano inferred by VLF surveys". Journal of Applied Geophysics 58.4, pp. 265-279. Dor: $10.1016 /$ j . jappgeo . 2005.05 . 004.

Zurek, J., S. Moune, G. Williams-Jones, N. Vigouroux, and P.-J. Gauthier (2019). "Melt inclusion evidence for long term steady-state volcanism at Las SierrasMasaya volcano, Nicaragua". Journal of Volcanology and Geothermal Research. Dor: 10 . 1016 / j . jvolgeores.2019.04.007.

\section{A Appendix 1}

Supplementary tables (Table A1 and Table A2). 
Table A1 - Structural features and locations displayed (as numbered abbreviations) in Figure 2. UTM coordinates (zone 16P) correspond with the centre (or midpoint in linear features) of the respective structures, with predominant bearing specified if appropriate.

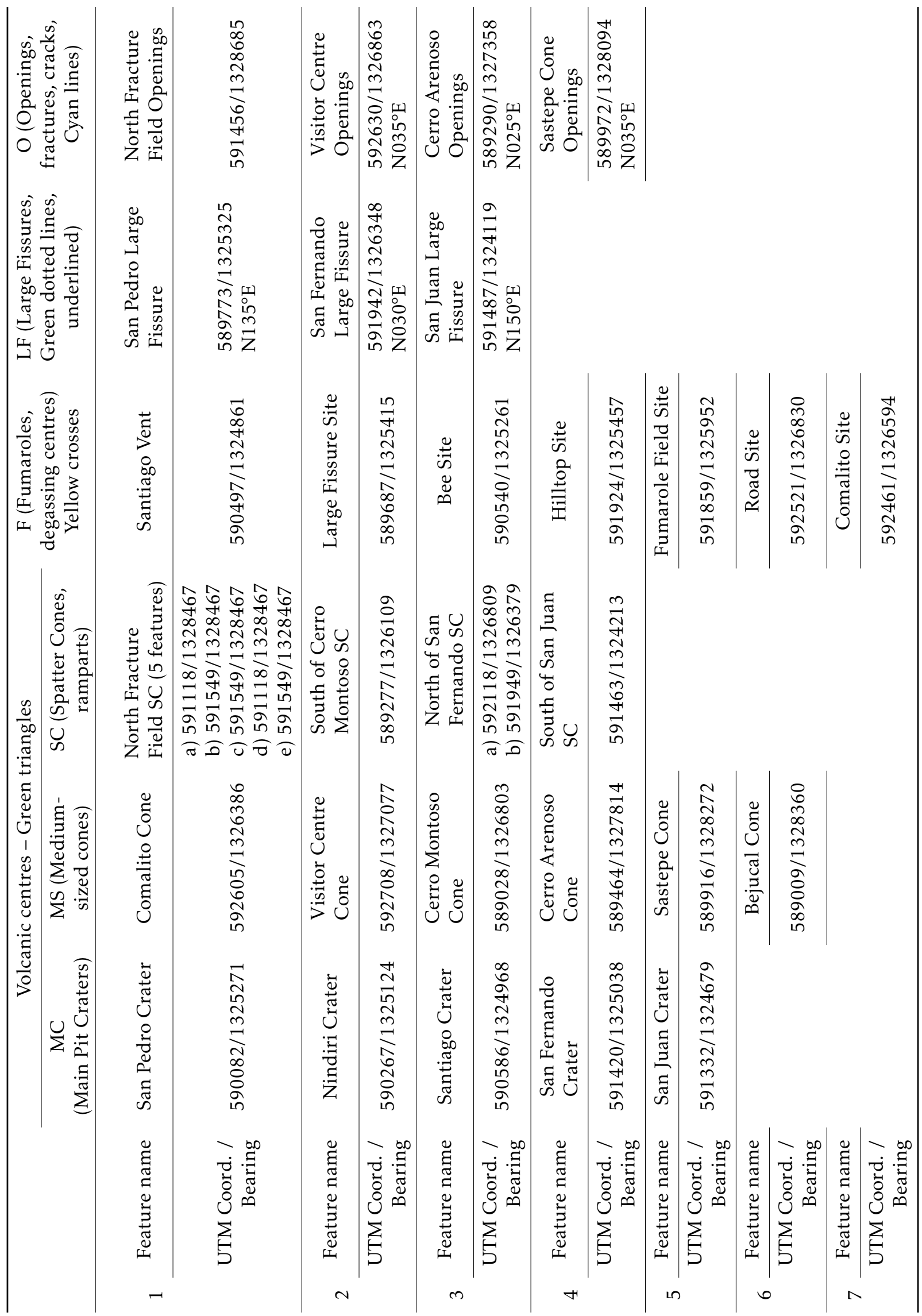


Table A2 - InSAR acquistions for Masaya volcano, Nicaragua.

\begin{tabular}{ccccccc}
\hline Master date & Slave date & Time Spanned (days) & Approximate Bperp $(\mathrm{m})$ & Track & Frame & Orientation \\
\hline 10 Oct. 2007 & 25 Feb. 2008 & 138 & 339 & 165 & 230 & Ascending \\
10 Oct. 2007 & 12 Oct. 2008 & 368 & -987 & 165 & 230 & Ascending \\
25 Nov. 2007 & 25 Feb. 2008 & 92 & 282 & 165 & 230 & Ascending \\
25 Feb. 2008 & 12 Oct. 2008 & 230 & -1406 & 165 & 230 & Ascending \\
12 Oct. 2008 & 27 Nov. 2008 & 46 & 102 & 165 & 230 & Ascending \\
27 Nov. 2008 & 14 Apr. 2009 & 138 & 736 & 165 & 230 & Ascending \\
30 Aug. 2009 & 30 Nov. 2009 & 92 & -183 & 165 & 230 & Ascending \\
30 Nov. 2009 & 18 Jul. 2010 & 230 & 302 & 165 & 230 & Ascending \\
30 Nov. 2009 & 15 Jan. 2010 & 46 & -26 & 165 & 230 & Ascending \\
02 Jun. 2010 & 18 Jul. 2010 & 46 & -45 & 165 & 230 & Ascending \\
15 Jan. 2010 & 02 Jun. 2010 & 138 & 373 & 165 & 230 & Ascending \\
27 Sep. 2007 & 28 Dec. 2007 & 368 & 508 & 470 & 3380 & Descending \\
28 Dec. 2007 & 29 Mar. 2008 & 92 & 74 & 470 & 3380 & Descending \\
29 Mar. 2008 & 14 May 2008 & 46 & -302 & 470 & 3380 & Descending \\
29 Sep. 2008 & 14 Nov. 2008 & 46 & -114 & 470 & 3380 & Descending \\
14 Nov. 2008 & 01 Apr. 2009 & 138 & 542 & 470 & 3380 & Descending \\
\hline
\end{tabular}

